\title{
Biogeographical patterns of Myrcia s.l. (Myrtaceae) and their correlation with geological and climatic history in the Neotropics
}

\author{
Matheus Fortes Santos ${ }^{a, b, *}$, Eve Lucas ${ }^{c}$, Paulo Takeo Sano ${ }^{a}$, Sven Buerki ${ }^{d}$, \\ Vanessa Graziele Staggemeier ${ }^{\mathrm{e}}$, Félix Forest ${ }^{\mathrm{b}}$ \\ a Universidade de São Paulo, Instituto de Biociências, Depto. Botânica, Lab. Sistemática Vegetal, R. do Matão 277, 05508-090 São Paulo, SP, Brazil \\ ${ }^{\mathrm{b}}$ Jodrell Laboratory, Royal Botanic Gardens, Kew, Richmond, Surrey TW9 3DS, United Kingdom \\ ${ }^{\mathrm{c}}$ Herbarium, Royal Botanic Gardens, Kew, Richmond, Surrey TW9 3AB, United Kingdom \\ ${ }^{\mathrm{d}}$ Department of Life Sciences, Natural History Museum, Cromwell Road, London SW7 5BD, United Kingdom \\ e Universidade Estadual Paulista Júlio de Mesquita Filho, Instituto de Biociências de Rio Claro, Av. 24A 1515, Caixa Postal 131, 13506-900 Rio Claro, SP, Brazil
}

\section{A R T I C L E I N F O}

\section{Article history:}

Received 13 July 2016

Revised 24 November 2016

Accepted 19 January 2017

Available online 1 February 2017

\section{Keywords:}

Amazon Forest, Atlantic Forest

Calyptranthes

Caribbean

Guiana Shield

Plant diversity

\begin{abstract}
A B S T R A C T
Many recent studies discuss the influence of climatic and geological events in the evolution of Neotropical biota by correlating these events with dated phylogenetic hypotheses. Myrtaceae is one of the most diverse Neotropical groups and it therefore a good proxy of plant diversity in the region. However, biogeographic studies on Neotropical Myrtaceae are still very limited. Myrcia s.l. is an informal group comprising three accepted genera (Calyptranthes, Marlierea and Myrcia) making up the second largest Neotropical group of Myrtaceae, totalling about 700 species distributed in nine subgroups. Exclusively Neotropical, the group occurs along the whole of the Neotropics with diversity centres in the Caribbean, the Guiana Highlands and the central-eastern Brazil. This study aims to identify the time and place of divergence of Myrcia s.l. lineages, to examine the correlation in light of geological and climatic events in the Neotropics, and to explore relationships among Neotropical biogeographic areas. A dated phylogenetic hypothesis was produced using BEAST and calibrated by placing Paleomyrtinaea princetonensis (56 Ma) at the root of the tree; biogeographic analysis used the DEC model with dispersal probabilities between areas based on distance and floristic affinities. Myrcia s.l. originated in the Montane Atlantic Forest between the end of Eocene and early Miocene and this region acted as a secondary cradle for several lineages during the evolution of this group. The Caribbean region was important in the diversification of the Calyptranthes clade while the Guayana shield appears as ancestral area for an older subgroup of Myrcia s.l. The Amazon Forest has relatively low diversity of Myrcia s.l. species but appears to have been important in the initial biogeographic history of old lineages. Lowland Atlantic Forest has high species diversity but species rich lineages did not originate in the area. Diversification of most subgroups of Myrcia s.l. occurred throughout the Miocene, as reported for other Neotropical taxa. During the Miocene, geological events may have influenced the evolution of the Caribbean and Amazon forest lineages, but other regions were geological stable and climate changes were the most likely drivers of diversification. The evolution of many lineages in montane areas suggests that Myrcia s.l. may be particularly adapted to such environments.
\end{abstract}

(C) 2017 Elsevier Inc. All rights reserved.

\section{Introduction}

The Neotropical region encompasses a wide range of geological and geomorphological formations, including young landscapes

\footnotetext{
* Corresponding author at: Universidade Federal de São Carlos, Campus Sorocaba, Departamento de Biologia, Rod. João Leme dos Santos (SP 264), km 110, 18052-780 Sorocaba, SP, Brazil.

E-mail addresses: matheus_fs@yahoo.com.br (M.F. Santos), e.lucas@kew.org (E. Lucas), ptsano@usp.br (P.T. Sano), s.buerki@nhm.ac.uk (S. Buerki),v.staggemeier @gmail.com (V.G. Staggemeier), f.forest@kew.org (F. Forest).
}

such as the Amazon basin (Neogene; Hoorn et al., 2010a), as well as old landscapes such as the Espinhaço Range (Proterozoic; Saadi, 1995). As a result of the large range of latitude (ca. $76^{\circ}$ ) and elevation (ca. $7000 \mathrm{~m}$ ), Neotropical climatic diversity is extensive (Köppen, 1948). Plant biodiversity is congruent with such environmental diversity; the Neotropics boasts enormous variation in vegetation types (Cabrera and Willink, 1980) and correspondingly high taxonomic diversity totalling between 90,000 and 110,000 species (Antonelli and Sanmartín, 2011). Recent studies have evaluated the influence of geological and climatic events 
in the generation of the Neotropical plant diversity. Congruence between these events and time and place of lineage origin has been tested through dated phylogenies and biogeographic analyses (Antonelli et al., 2009; Perret et al., 2013; Fine et al., 2014).

The main geological events influencing Neotropical biogeography were the isolation of South America, Andean uplift and the closure of the Isthmus of Panama (Burnham and Graham, 1999). The connection between South America, Antarctica and Australia and their subsequent separation after the isolation of Antarctica influenced the early diversification of Neotropical groups, including Myrtaceae (Sytsma et al., 2004; Lucas et al., 2007; Buerki et al., 2011; Labiak et al., 2014). The Andean uplift had multiple consequences for the Neotropical landscape such as the formation of the Amazon basin, the Pebas system and the creation of new habitats (e.g., white sand and flooded soils), which influenced the diversification of different groups (Antonelli et al., 2009; Hoorn et al., 2010a, 2010b; Roncal et al., 2013; Fine et al., 2014). Closure of the Isthmus of Panama also had impact on the evolutionary history of plant taxa, allowing intense floristic exchange between South America and Mesoamerica (Richardson et al., 2001; Bacon et al., 2013).

Global transition to colder climates during the Paleogene and Neogene (Zachos et al., 2001; Graham, 2010) influenced the diversification of groups in different biomes (Antonelli et al., 2010; Hughes et al., 2013). The two highly species diverse biomes of Central-Eastern Brazil (Atlantic Forest and Cerrado) are located in an area that has undergone little geological change but significant climatic changes during the Cenozoic. Pleistocene climate changes in the Atlantic Forest (Carnaval and Moritz, 2008) are mentioned as important events that drove the evolution of recent lineages of plants (Martins, 2011). Climatic fluctuations of the Neogene and Quaternary connected the Northern Atlantic and Amazon forests, resulting in conflicting biogeographic relationships between the Amazon forest and the northern and southern parts of the Atlantic forest (Perret et al., 2006; Santos et al., 2007; Fiaschi and Pirani, 2009). Diversification of Cerrado taxa is hypothesized to be linked to climatic changes (low precipitation and high climatic seasonality), expansion of C4 grass and fire events (Simon et al., 2009; Simon and Pennington, 2012).

Plant evolution of other highly diverse Neotropical regions also show biogeographical patterns. Taxa from the Guiana Shield emerge from deep nodes in phylogenetic hypothesis and the Guayana region has been found as an ancestral area in some groups (Givnish et al., 2004, 2011; Struwe et al., 2009; Roncal et al., 2013). Biogeographic relationships between Guayana and Brazilian montane taxa and correlation with the separation of the Guayana and Brazilian shields has been suggested (Givnish et al., 2011). Origin of Caribbean taxa has been explained both by a Northern origin or a Southern origin through long-dispersal, for different groups (Santiago-Valentín and Olmstead, 2004; Fine et al., 2014).

Several plant groups have been the focus of biogeographic studies but many remain poorly studied such as Myrtaceae and most of its genera, including the large Myrcia s.l. (700 spp.; Govaerts et al., 2016). Lucas et al. (2007) studied the biogeography of Myrteae using a Dispersal vicariance analysis (DIVA; Ronquist, 1997), but did not find an unequivocal ancestral area for Myrcia s.l. and internal relationships were not discussed. Biffin et al. (2010) suggested a rapid diversification of Myrcia s.l. in the Early Miocene, but again internal relationships were not considered. Staggemeier et al. (2015) studied Myrcia sect. Aulomyrcia (clade 9 of Lucas et al., 2011) and found lower extinction rates and accumulation of species inside Pleistocene forest refugia of the Atlantic Forest. Lucas et al. (2011) speculated that after the colonization of the southernmost parts of South America by Myrteae ancestors, Myrcia s.l. ancestors migrated north and east through tropical forests and subsequently dispersed northward. Andean uplift and its consequences in the continental vegetation would have been concomitant with the early Miocene diversification of Myrcia s.l. in the Atlantic and northwest Amazon forests, as well as in the grasslands between them; the formation of the Isthmus of Panama would have allowed the migration of Caribbean taxa (Lucas et al., 2011).

Groups with wide distribution and high species diversity in the Neotropical region allow the examination of an overall relationship between different biogeographic regions. The high diversity of Myrcia s.l. suggests that it is a potential proxy of the plant biogeography in the region, as the entire Myrtaceae in Australasia (e.g., Ladiges et al., 2003). Therefore, the aims of the study are: (1) to identify the time and place of divergence in Myrcia s.l. lineages focusing in the subgroups diagnosed by Lucas et al. (2011); (2) to examine the spatial and temporal relationship between biogeographic patterns of Myrcia s.l. and geological and climatic events during the Cenozoic in Neotropics; (3) to explore relationship among biogeographic areas of Neotropics.

\section{Materials and methods}

\subsection{Taxonomy and diversity of Myrcia s.l}

Myrcia s.l. (Fig. 1) is an informal group proposed by Lucas et al. (2007; as the Myrcia group) in a phylogenetic study of tribe Myrteae (sensu Wilson et al., 2005). Myrcia s.l. is the second largest Neotropical group of Myrtaceae (Govaerts et al., 2016). Exclusively Neotropical, Myrcia s.l. is distributed along the whole region with diversity centres in the Caribbean, the Guiana Highlands and the central-eastern Brazil (McVaugh, 1968, 1969). It includes three accepted genera: Calyptranthes Sw., Marlierea Cambess. and Myrcia DC. (Govaerts et al., 2016). Lucas et al. (2011) conducted a phylogenetic study with these genera and diagnosed nine clades, showing that Marlierea and Myrcia are polyphyletic, while Calyptranthes is monophyletic but embedded within the former two. These nine clades of Myrcia s.l. form the basis of an infrageneric classification with nine sections that will include Calyptranthes and Marlierea under Myrcia. These nine clades are referred from here forward as Myrcia s.l. subgroups.

The diversity of the nine clades of Lucas et al. (2011) is not equally divided among the diversity centres of Myrcia s.l. Clade 1 (similar to Calyptranthes) contains about 280 spp. with its main diversity in the Atlantic Forest, Guiana Highlands and Caribbean (McVaugh, 1969; Lucas et al., 2011; Govaerts et al., 2016). Clades 2 (ca. 20 spp.) and 3 (ca. 60 spp., similar to the genus Gomidesia O.Berg) occur mainly in the Atlantic Forest (Lucas et al., 2011; Govaerts et al., 2016; Sobral et al., 2016). Clade 6 (ca. 20 spp.) has its species concentrated in the Atlantic Forest and associated montane open vegetation (Lucas et al., 2011). Clade 7 (= Myrcia sect. Sympodiomyrcia; ca. 20 spp.) is distributed in montane areas of Atlantic Forest and Campo Rupestre vegetation with three disjunct species in the Guayana Region (Santos et al., 2016). Clade 9 (= Myrcia sect. Aulomyrcia; ca. 130 spp.) has its diversity divided between the Atlantic Forest, Amazon Forest and Guiana Highland (Lucas et al., 2016). Clades 4 (ca. 50 spp.), 5 (ca. 100 spp.) and 8 (ca. $10 \mathrm{spp}$.) have their diversities equally spread throughout the distribution of Myrcia s.l. (Lucas et al., 2011).

\subsection{Sampling and data collection}

Molecular sequences were accessed from previous phylogenetic studies in Myrteae and Myrcia s.l. (Lucas et al., 2007, 2011; Staggemeier et al., 2015; Santos et al., 2016; Wilson et al., 2016). One nuclear and four chloroplast DNA markers were used (supplementary Table 1 of Appendix A). These respectively, were ITS, $n d h F$, psbA-trnH, trnL-trnF and trnQ-5'rps16. The sample of Myrcia s.l. 

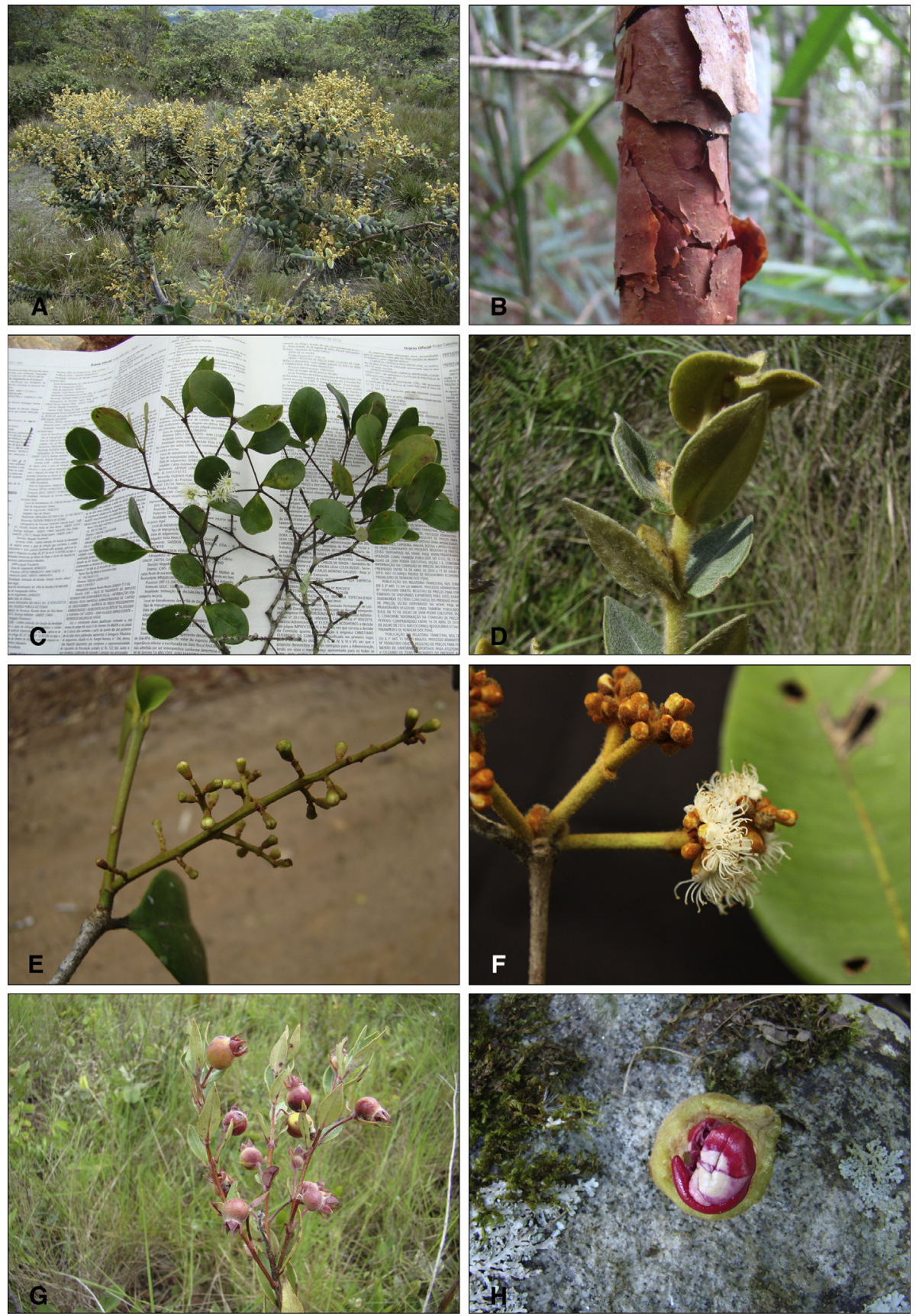

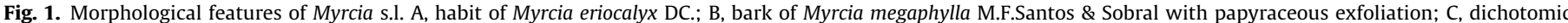

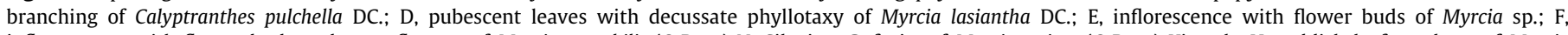

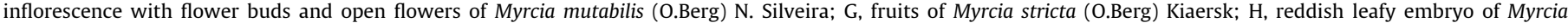
ferruginosa Mazine.

species used is the largest assembled to date; all available sequences of Myrcia s.l. were considered. In total, 182 samples (173 species) were used including taxa from all nine subgroups and 13 outgroup taxa for improved accuracy of molecular dating (supplementary Table 2 of Appendix A). Sampling covers around 25\% of Myrcia s.l. species diversity, which is acceptable representation because all clades and biogeographic regions are represented in the phylogenetic analysis. Sampling covers around 50\% of the central-eastern Brazil diversity centre (areas D-G and I, see Section 2.4), ca. $15 \%$ for the Caribbean, Mesoamerica and NW South America; ca. 20\% for Amazon forest; ca. 30\% for Guayana region (percentages based on the databases of Govaerts et al., 2016 and Sobral et al., 2016).

\subsection{Data edition and phylogenetic analysis}

Sequences were aligned using the default parameters of Muscle (Edgar, 2004) conducted on Geneious 6.1.6 (Drummond et al., 2013). Final alignments were visually checked to minimise number and size of gaps. Models of nucleotide substitution were calculated for each marker using MrModeltest2 version 2.2 (Nylander, 2004) implemented using PAUP* 4.0b2 (Swofford, 2002). Selected models under the Akaike Information Criterion were: GTR $+\mathrm{I}+\mathrm{G}$ for ITS, psbA-trnH and trnQ-5'rps16; and GTR + G for $n d h F$ and trnLtrnF.

Bayesian analysis was conducted in BEAST 1.8.0 (Drummond and Rambaut, 2007) using the combined data set. Site and clock 
models were implemented independently for each region. The prior substitution rate was defined as uniform and molecular clock model as lognormal relaxed clock (uncorrelated) for all partitions. Tree priors were set as a Yule speciation process. Myrtus communis was assigned as the outgroup taxon and the internal group was set as monophyletic.

Calibration of phylogenetic trees is a subjective process that varies depending on the practitioner. In this study the tree was calibrated using Paleomyrtinaea princetonensis Pigg, Stockey \& Maxwell (Pigg et al., 1993). The study followed Staggemeier et al. (2015) and placed this fossil at the root of the tree, using a lognormal distribution with median age of $56 \mathrm{Ma}$, offset to $55 \mathrm{Ma}$ with a standard deviation of 1.0. An older fossil assigned to Myrteae (Myrceugenelloxylon antarcticus Poole, Hunt \& Cantrill), from ca. 72-66 Ma (Maastrichtian age - Upper Cretaceous; Poole et al., 2003) was also considered. However, the absence of diagnostic characters of Myrtaceae wood, such as presence of vestured pits (Oskolski, pers. comm.), led us to disregard this fossil. The fossil wood of Myrceugenia chubutense Ragonese (1980) was not used because its radially extended vessel-ray pits that are said to be diagnostic for Myrceugenia have been found in other Myrtaceae genera from temperate parts of South America such as Luma (InsideWood, 2004-onwards) meaning that the fossil would need to be placed at the root of Myrteae; such placement produces similar nodes ages to those found here (Vasconcelos et al., 2017). Murillo-A et al. (2016) use Myrceugenia chubutense to calibrate Myrceugenia and Myrceugenelloxylon antarcticus to calibrate the node from which Luma arises, thereby greatly increasing node ages beyond those returned by any other study. Fossil pollen employed by Thornhill et al. (2012) is not used here as those authors state that using macrofossil or macrofossil plus pollen fossil produces congruent results. Further justification for the calibration used here is from Vasconcelos et al. (2017) who present a comprehensive comparative review of the use of fossils for calibration in Myrteae and find similar results when conservatively using macrofossils and pollen; those authors find node dates that match those presented here.

Bayesian analysis was conducted with 400 million generations of Monte Carlo Markov chains and sampling frequency of 1000. The file with matrix and parameters was assembled in BEAUti
1.8.0 (Drummond and Rambaut, 2007). Analysis in BEAST was run on the CIPRES portal (Miller et al., 2010). Outcomes of Bayesian analysis were visualized in Tracer 1.4 .1 (Rambaut et al., 2013) to examine convergence and sufficiency of effective sample size (i.e., higher than 200), ensuring good representation of the posterior distributions. A maximum clade credibility tree with median branch lengths and a 95\% highest posterior density interval on nodes was generated in TreeAnnotator 1.8.0 (Drummond and Rambaut, 2007) using the standard burn-in of $10 \%(40,000$ trees in this case).

\subsection{Delimitation of biogeographic areas}

The biogeographic areas proposed by Cabrera and Willink (1980) and Morrone $(2006,2014)$ are the basis of the areas delimited here (Fig. 2). These were modified to adjust area limits to the diversity of Myrcia s.l., to incorporate evidence of biogeographic patterns from other studies, and to minimise the number of areas, due to restrictions of the DEC analysis (see Ree and Smith, 2008). All areas include different types of vegetation, but the discussion is focused in the main type (in terms of area) that occurs in each area unless clearly stated. The concept of Neotropical region follows Morrone (2006).

A. Caribbean. This area is formed by the Antilles area of Morrone (2014) that includes the islands of the Caribbean Sea.

B. Amazon Forest. This area includes the South-eastern Amazonia, the South-western Amazonia and part of the Northern Amazonia (except the upper part of Rio Negro basin) of Morrone (2014). The fusion of Amazon areas is due to the low level of endemism in Myrcia s.l. (McVaugh, 1968, 1969).

C. Guayana Region. This area is composed of the Guiana Highlands and surrounding lowland areas including the upper part of Rio Negro basin and North-eastern Venezuela, Guiana, Suriname and part of French Guiana. This delimitation follows the Guayana Region of Berry et al. (1995) and covers most of the Guiana Shield. The unit includes Venezuela, removed from North-western South America and the Rio Negro basin removed from Northern Amazonia (Morrone, 2014). Guayana region was proposed as an independent area due to high levels of Myrcia s.l. endemism in the region (McVaugh, 1968, 1969).

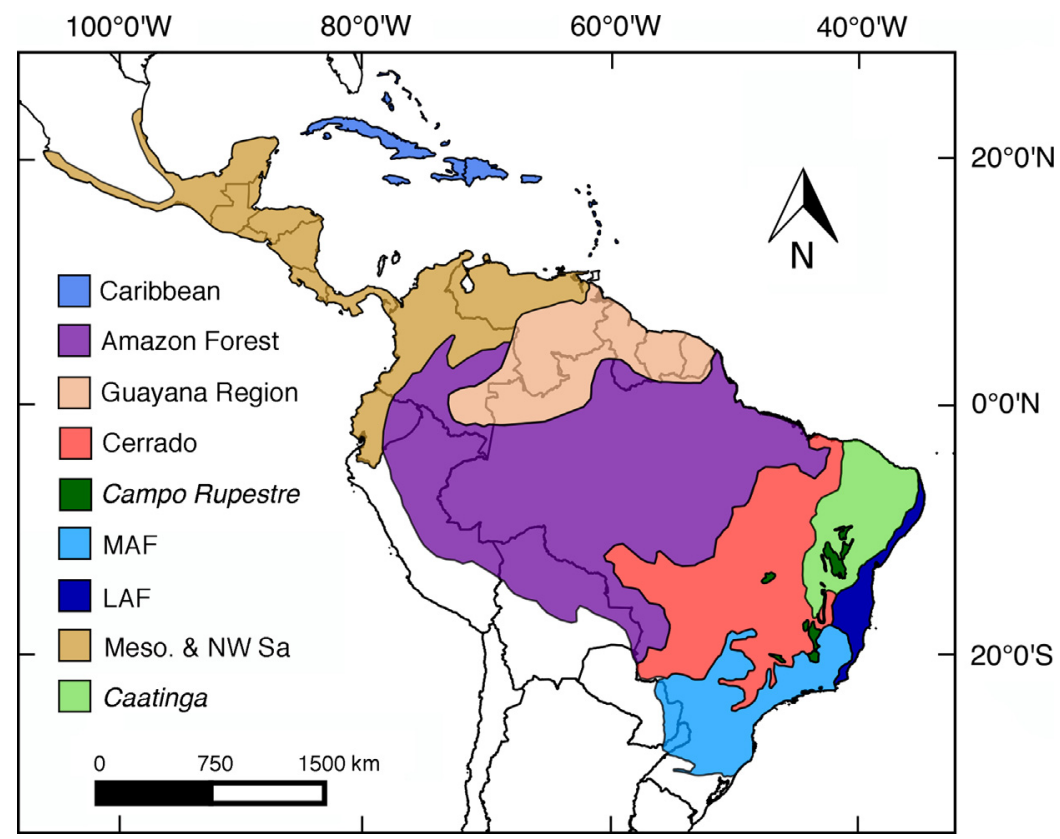

Fig. 2. Biogeographic areas defined for this study. Borders of South and Central America countries are shown. 
D. Cerrado. This area includes only the savanna vegetation of the Chaco (sensu Morrone, 2014). Chaco vegetation was excluded as none of the species in the analysis occurs in this vegetation type (Govaerts et al., 2016; Sobral et al., 2016).

E. Campo Rupestre. This area is composed of Campo Rupestre vegetation (Giulietti and Pirani, 1988; Harley, 1995; Rapini et al., 2008; Silveira et al., 2016) that occurs in the Chaco (sensu Morrone, 2014). This vegetation is found in quartzitic montane areas of Central-eastern Brazil (Giulietti and Pirani, 1988). Despite similarity between Campo Rupestre and Cerrado (both open areas, i.e., without canopy), environmental and floristic differences (Harley, 1995; Rapini et al., 2008) support their consideration as distinct areas. There is significant difference in Myrcia s.l. species composition between these two vegetation types (e.g., Clade 7; Santos et al., 2016).

F. Montane Atlantic Forest (MAF). This area includes the southern part of the Paraná unit of Morrone (2014), from the Mixed Rain Forest (the Araucaria angustifolia Forest Province of Morrone, 2006) to the region around the mouth of the Rio Doce. Unlike the northern part of Atlantic forest that is a narrow strip along coastal areas (Fiaschi and Pirani, 2009), the southern part of that Atlantic Forest encompasses large areas of inland semideciduous forest (Oliveira-Filho and Fontes, 2000; Oliveira-Filho et al., 2006). This unit includes most montane Atlantic Forest although some Northern montane areas are included in the Lowland Atlantic Forest unit as available surveys suggest a higher floristic similarity with the surrounding lowland forests (Oliveira-Filho et al., 2006; Santos et al., 2007).

G. Lowland Atlantic Forest (LAF). This area corresponds to the northern part of the Paraná unit of Morrone (2014) mostly including lowland Atlantic Forest (a rainforest usually referred as Tabuleiro Forest) that occurs from the North of Rio de Janeiro State (Brazil) to the northernmost limit of Atlantic Forest (Thomas and Barbosa, 2008; Fiaschi and Pirani, 2009). The North/South Atlantic Forest division has been highlighted by previous studies (Mori et al., 1981; Thomas et al., 1998; Perret et al., 2006; Murray-Smith et al., 2008). The northernmost Atlantic Forest is also considered a distinct centre of endemism (the PernambucoAlagoas Centre; Thomas et al., 1998) but is not separated here due to low levels of Myrcia s.l. diversity and endemism.

H. Mesoamerica and NW South America. This area unites Mesoamerica and the North-Western South America units of Morrone (2014). Both areas have low diversity of Myrcia s.l. (Govaerts et al., 2016; Sobral et al., 2016) and are included here to accommodate few non-endemic species. The biogeographic affinity of these areas was documented by Morrone (2014).

I. Caatinga. This area includes only the Caatinga vegetation of the Chaco (sensu Morrone, 2014). Like the previous region, Caatinga boasts few species of Myrcia s.l. (Govaerts et al., 2016; Sobral et al., 2016) and is included to house non-endemics.
J. Extra-Neotropics. Luma apiculata, Myrceugenia ovata, Myrceugenia planipes and Myrtus communis are outgroup taxa with extraNeotropical distributions that occur in other biogeographic regions. The first three taxa occur in Central Chile while Myrtus communis is endemic to the Mediterranean. Placing them all in this single generic category minimises the total number of biogeographic units required.

\subsection{Biogeographic analysis}

The dispersal-extinction-cladogenesis model (DEC; Ree and Smith, 2008) was used to reconstruct the biogeographic history of Myrcia s.l. over the phylogenetic hypothesis. A binary matrix of species presence/absence per biogeographic area was compiled (supplementary Table 2 of Appendix A) using data from Sobral et al. (2016), Govaerts et al. (2016), CRIA (2016) and herbarium collections.

DEC analysis was carried out using RASP 3.2 (Yu et al., 2015). Two models were used, one with default parameters (MDP) and other with selected parameters (MSP); in doing this, we aimed to analyse the influence of parameter choice in the analysis. The number of ancestral areas ("maximum range size") was implemented as two, preventing high numbers that might result in slower analysis and less resolution. Ancestral areas were estimated for all nodes. In the MSP, the range constraints limited ancestors to inhabiting only the combination of biogeographic units with dispersal constraints equal or bigger than 0.5 (Table 1 ).

Dispersal constraints were based primarily on area proximity with evidence of floristic connections as auxiliary criteria (Table 1 ). Dispersal values between adjacent units or non-adjacent units with past or present floristic connections (i.e., Amazon Forest $\times$ MAF and LAF) were set up as 1.0 with exceptions for the Guayana Region and Campo Rupestre whose dispersal values were set at 0.5 despite the floristic connection (Giulietti and Pirani, 1988), due to substantial geographic separation. Non-adjacent areas with small geographic distances $(<2000 \mathrm{~km}$, e.g., Amazon Forest $\times$ Campo Rupestre, Guayana Region $\times$ Cerrado) were also assigned dispersal values of 1.0. No dispersal value was assigned as zero due to reports of Neotropical long-distance dispersals (e.g., Givnish et al., 2004). Probabilities of areas being ancestral are represented as pie charts on the resulting chronogram; these indicate the areas with probability higher than 0.5 and unite the others into a single category.

Time slices were not implemented in the biogeographic analysis as each area has likely existed with similar connections during the period covered by the molecular dating (Eocene to the Holocene). For example, the Caribbean was connected to South America during the Paleogene and Neogene (Gentry, 1982; Iturralde-Vinent and MacPhee, 1999; Graham, 2010) making it difficult to establish different parameters throughout the period. Despite geological

Table 1

Dispersal constraints used in the model with selected parameters.

\begin{tabular}{|c|c|c|c|c|c|c|c|c|c|c|}
\hline & Caribbean & Amazon F. & Guayana R. & Cerrado & $\mathrm{CR}$ & MAF & LAF & Meso. \& NW SA & Caatinga & EN \\
\hline Caribbean & - & 0.1 & 0.5 & 0.001 & 0.001 & 0.001 & 0.001 & 1.0 & 0.001 & 0.001 \\
\hline Amazon F. & - & - & 1.0 & 1.0 & $1.0^{\mathrm{b}}$ & $1.0^{\mathrm{a}}$ & $1.0^{\mathrm{a}}$ & 1.0 & 1.0 & 0.001 \\
\hline Guayana R. & - & - & - & $1.0^{\mathrm{b}}$ & $0.5^{\mathrm{a}}$ & 0.001 & 0.1 & 1.0 & 0.1 & 0.001 \\
\hline Cerrado & - & - & - & - & 1.0 & 1.0 & 1.0 & 0.001 & 1.0 & 0.001 \\
\hline $\mathrm{CR}$ & - & - & - & - & - & 1.0 & 1.0 & 0.001 & 1.0 & 0.001 \\
\hline MAF & - & - & - & - & - & - & 1.0 & 0.001 & 1.0 & 0.001 \\
\hline LAF & - & - & - & - & - & - & - & 0.001 & 1.0 & 0.001 \\
\hline Meso. \& NW SA & - & - & - & - & - & - & - & - & 0.001 & 0.001 \\
\hline Caatinga & - & - & - & - & - & - & - & - & - & 0.001 \\
\hline
\end{tabular}

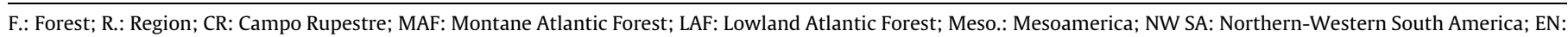
Extra-Neotropical.

a Non-adjacent biogeographic areas, but with floristic connections.

b Non-adjacent biogeographic areas, but distance $<2000 \mathrm{~km}$ from each other. 
changes in the Amazon Forest during the Neogene (Hoorn et al., $2010 b)$, forest areas were present in the region since the Paleocene (Jaramillo et al., 2010; Graham, 2012). The Guayana Region has undergone geomorphological changes during the Neogene but at least some regions have been exposed since the Paleogene (Wesselingh et al., 2010). Simon et al. (2009) suggest the expansion of $\mathrm{C} 4$ grasses around $4 \mathrm{Ma}$ was the main cause of Cerrado emergence, but other evidence suggests similar vegetation in central South America considerably earlier (Van der Hammen, 1983). Paleoenvironmental records for Campo Rupestre are scanty, but surfaces in the Espinhaço range, the core area of this vegetation type, have been exposed since the Mesozoic (Saadi, 1995; Almeida-Abreu and Renger, 2002). Little data exists concerning MAF and LAF, but the tropical forest is believed to have been present in these areas since the Paleogene (Morley, 2000; Burnham and Johnson, 2004).

\section{Results}

\subsection{Phylogenetic analysis}

The ESS of all markers in the Bayesian analysis exceeded 200, indicating they had a good statistical sampling of the posterior distributions of the data. The cladogram resulting from Bayesian analysis (Fig. 3) shows Myrcia s.l. to have been recovered as monophyletic and sister to the Plinia Group. Myrcia s.l. subgroups were recovered with PP higher than 0.9, except clade 9, which was separated in two groups (Fig. 3). A clade formed by Myrcia aff. maximiliana O.Berg and Myrcia robusta Sobral (PP 1.0) did not show affinity with any clade proposed by Lucas et al. (2011). Other clades receiving PP higher than 0.9 , include a large clade composed by the clades $1,2,3,4,6,7$ and 8 .

\subsection{Molecular dating of nodes}

Intervals of 95\% Highest Posterior Density (HPD) of divergence for nodes with PP higher than 0.9 are shown in Fig. 3; those discussed are summarised in Table 2 . The 95\% HPD intervals are wide, likely due to the use of a single fossil for calibration. The crown node of Myrcia s.l. has an age of 36.1-21.1 Ma (95\% HPD), indicating an origin between end of Eocene and early Miocene. Ages of the Myrcia s.l. subgroups varied with the oldest reported for part of clade 9 (9b) at 29.0-15.9 Ma (95\% HPD; end of Oligocene to middle Miocene) and the youngest, clade 8 at 9.8-2.5 Ma (95\% HPD; end of Miocene to end of Pliocene).

Despite the relatively large variation, all nodes fall in the Neogene except the upper 95\% HPD limit for clades 1 and 9. Node ages within the Myrcia s.l. subgroups are also from the Neogene, with rare diversifications in the Quaternary. Node ages inside the Quaternary are found mainly in clades originating from most recent nodes with low statistical support.

\subsection{Comparison of model parameters}

The biogeographic hypotheses generated by the MDP (supplementary Figs. 1 and 2 of Appendix A) and MSP (Fig. 4) return the same overall patterns but with meaningful differences. Likelihood of MSP was higher than likelihood of MDP $(-\ln L=453.4$ and $-\ln \mathrm{L}=491.8$, respectively). Under MSP, constraining range and dispersal resulted in fewer ancestral areas per node, allowing clearer hypothesis of ancestral areas. The constraints also decreased the probability of unlikely combinations of ancestral areas (e.g., Caribbean plus MAF). Section 3.4 and the discussion of this work are based on the biogeographic hypothesis generated using MSP as it incorporates more realistic biogeographic scenarios.

\subsection{Biogeographic reconstruction}

The biogeographic hypothesis generated from the MSP indicates many nodes with high probability of ancestral area(s) (Fig. 4; Table 2). A major finding is that MAF is highly likely to be the ancestral area for most Myrcia s.l. subgroups (clades 2, 3, 6 and 7) (Figs. 3 and 4; Table 2). Some inclusive clades (e.g., node 261; Table 2) also have MAF as the most likely ancestral area.

The most likely ancestral area of clade $9 \mathrm{~b}$ is the Guayana Region plus the Amazon Forest. The Amazon Forest and Caribbean appears to have been important areas during the diversification of older lineages of Calyptranthes (Fig. 4; Table 2). Campo Rupestre emerges as ancestral areas of some internal clades of the groups of Myrcia s. 1. (e.g., nodes 295 and 213, respectively), while the Cerrado apparently did not have major importance in the diversification of Myrcia s.l. (Fig. 4; Table 2). The oldest lineages of Myrcia s.l. tend to have less resolved ancestral areas, a shortcoming reported in other biogeographic analyses using the DEC model (Buerki et al., 2011). According to the analysis, the main process driving the biogeographic history is dispersal (global cost $=240$ ), while vicariance and extinction had small influences (global cost 29 and one, respectively).

\section{Discussion}

\subsection{Phylogenetic analysis}

Results broadly support those presented in previous papers (Lucas et al., 2011; Staggemeier et al., 2015). Low support for clade 9 and its division into two clades (clades 9a and 9b) was highly supported; this agrees with previous studies (Staggemeier et al., 2015; Santos et al., 2016) who also found low support for clade 9 (PP 0.5); however, Lucas et al. (2011) reported a PP higher than 0.9 . Clade 9 is morphologically consistent and supported by a diagnostic combination of characters (Lucas et al., 2016); further investigation is required to understand whether clade 9 is a single lineage or two lineages with independent evolutionary history. Inclusion of more taxa and markers provided higher support for phylogenetic structure within the Myrcia s.l. subgroups and for relationships between them.

\subsection{The southern origin of Myrcia s.l. and rapid expansion to northern South America}

Tribe Myrteae originated as part of the temperate flora of Australasia during the Paleocene (Sytsma et al., 2004; Lucas et al., 2007) and the "Antarctica route" was the likely path to the Americas (Pennington and Dick, 2004; Buerki et al., 2011; Labiak et al., 2014). After the opening of the Drake Passage and with the progressive isolation of Antarctica, Neotropical Myrtaceae were separated from the Australasian group (Sytsma et al., 2004; Lucas et al., 2007). The biogeographic hypothesis presented here shows MAF with the highest probability $(0.50$; Table 2$)$ of being the site of initial diversification of Myrcia s.l. The southern position of Atlantic Forest is congruent with the migration of Neotropical Myrteae ancestors through Antarctica. The ancestral area of the clade comprising most Myrcia s.l. subgroups (node 261) is MAF, while clades 1, 5, 9a and 9b apparently have more northern origins (Fig. 4; Table 2). The most likely subsequent scenario is diversification in southeast South America concurrent with an expansion to the north. Other Neotropical groups have followed a similar path, such as Alstroemeria (Alstroemeriaceae), Bignonieae (Bignoniaceae), Escallonia (Escalloniaceae), Rhipsalis (Cactaceae) and Weinmannia (Cunnoniaceae) (Fiaschi and Pirani, 2009; Calvente et al., 2011; Lohmann et al., 2013). The results are congruent with the rapid 


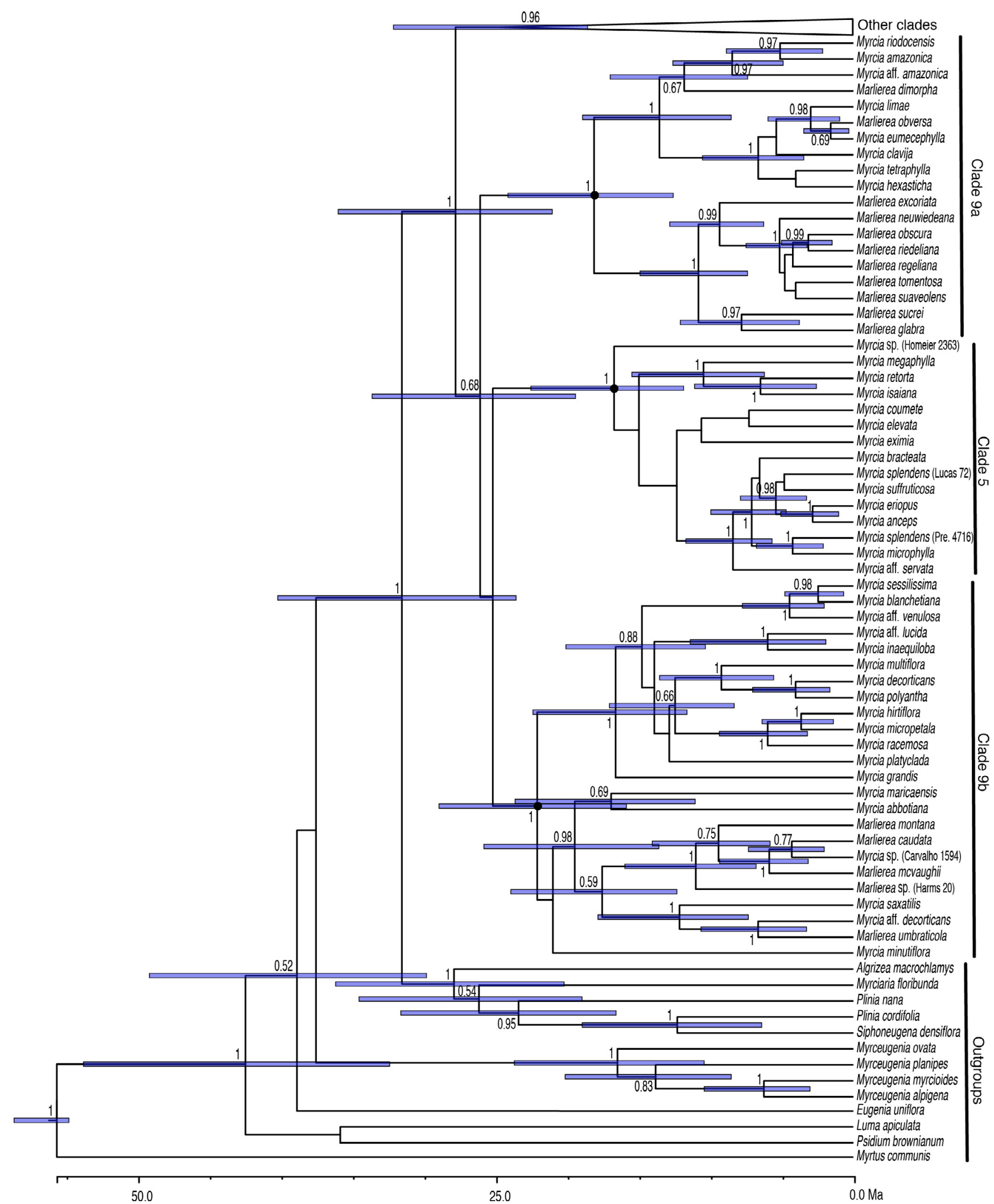

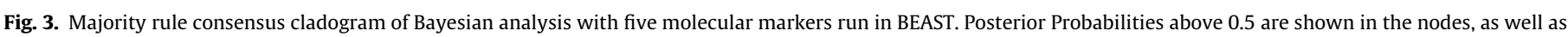

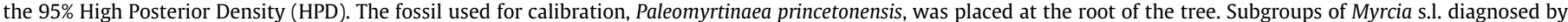
Lucas et al. (2011) are highlighted; clade 9 was divided in clade 9a and 9b. Full circles indicate crown nodes of these groups. Pre. = Prevost; Stagg. = Staggemeier.

diversification of Myrcia s.l. proposed by Biffin et al. (2010) and the biogeographic scenario proposed by Lucas et al. (2011).

Vegetation records from the Atlantic Forest during the Paleogene and Neogene are scanty. Forests are suggested to have covered MAF during the period encompassed by the crown node age of Myrcia s.l. (95\% HPD, 36-21 Ma) (Morley, 2000; Burnham and Johnson, 2004), and the ancestor of Myrcia s.l. might have inhabited them. Pollen and macrofossils indeed indicate a wet 


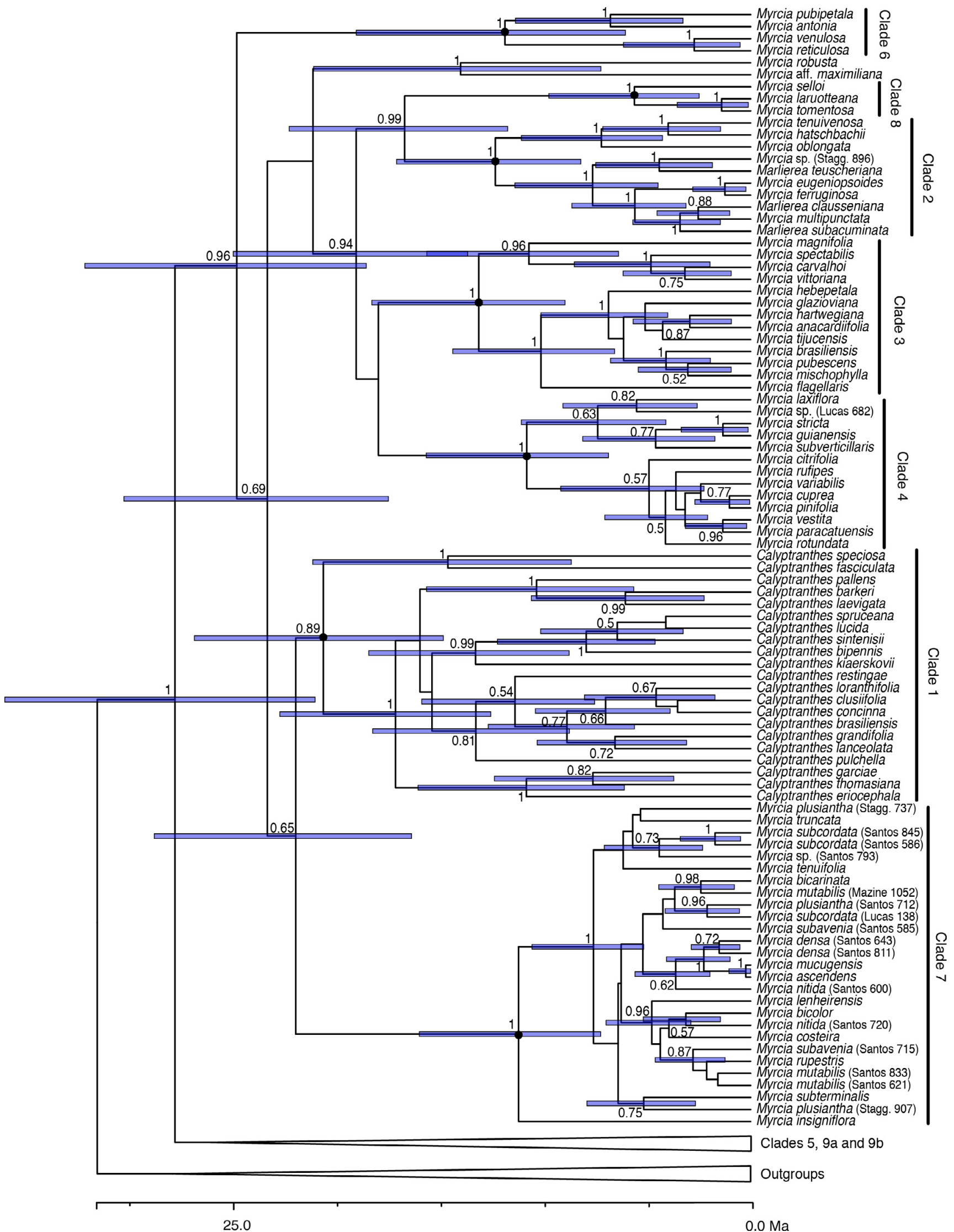

Fig. 3 (continued) 
Table 2

High Posterior Density (95\% HPD) age and the most probable ancestral area (probability in parenthesis) of nodes discussed in the text. Clades 1-8 are delimited according to Lucas et al. (2011); the clade 9 was divided in clade 9a and clade 9b. HAP: highest ancestral area probability. A. Caribbean; B. Amazon Forest; C. Guayana Region; D. Cerrado (savanna vegetation); E. Campo Rupestre; F. Montane Atlantic Forest; G. Lowland Atlantic Forest.

\begin{tabular}{|c|c|c|}
\hline Clade/node & 95\% HPD (Ma) & HAP \\
\hline Node 172 (Clade 6) & $19.1-6.1$ & $\mathrm{EF}(0.64)$ \\
\hline Node 175 (Clade 8 ) & $9.8-2.5$ & $\mathrm{~F}(0.64)$ \\
\hline Node 184 (Clade 2 ) & $17.1-8.2$ & $\mathrm{~F}(1.00)$ \\
\hline Node 186 & $15.7-6.4$ & $G(0.56)$ \\
\hline Node 197 (Clade 3) & $18.3-9.0$ & $\mathrm{~F}(0.82)$ \\
\hline Node 205 & $9.1-2.2$ & $\mathrm{D}(0.70)$ \\
\hline Node 209 (Clade 4) & $15.7-6.9$ & $\mathrm{DF}(0.44)$ \\
\hline Node 213 & $21.2-8.7$ & $\mathrm{~B}(0.46)$ \\
\hline Node 215 & $15.7-5.6$ & $A(1.00)$ \\
\hline Node 219 & $18.5-8.8$ & $\mathrm{AB}(0.77)$ \\
\hline Node 226 & $18.3-8.8$ & $\mathrm{~B}(0.36)$ \\
\hline Node 230 & $16.1-6.1$ & $A(1.00)$ \\
\hline Node 231 & $22.8-12.6$ & $\mathrm{AB}(0.84)$ \\
\hline Node 232 (Clade 1 ) & $26.9-14.9$ & $\mathrm{~B}(0.61)$ \\
\hline Node 244 & $4.1-1.0$ & $\mathrm{E}(1.00)$ \\
\hline Node 258 (Clade 7) & $16.0-7.3$ & $\mathrm{~F}(0.58)$ \\
\hline Node 261 & $32.2-18.6$ & $F(0.85)$ \\
\hline Node 279 (Clade 9a) & $24.2-12.6$ & $\mathrm{FG}(0.53)$ \\
\hline Node 293 (Clade 5) & $22.6-11.9$ & $\mathrm{BF}(0.53)$ \\
\hline Node 295 & $7.7-2.0$ & $\mathrm{E}(0.81)$ \\
\hline Node 300 & $9.4-3.2$ & $G(0.72)$ \\
\hline Node 305 & $24.4-11.6$ & $\mathrm{~B}(0.21)$ \\
\hline Node 316 (Clade 9b) & $29.0-15.9$ & $\mathrm{BC}(0.33)$ \\
\hline Node 319 (Myrcia s.1.) & $36.1-21.1$ & $F(0.50)$ \\
\hline
\end{tabular}

and warm forest, but also with evidences of dry periods with open vegetation (Lima, 1991; Biagolini et al., 2013). Connection of southern and northern South American forests may have occurred via different routes. Records of forests in Patagonia (OrtizJaureguizar and Cladera, 2006) indicate that the climate of South America was wet and warm throughout most of its range during the Oligocene-Middle Miocene, the diversification period of the first lineages of Myrcia s.l. This climate would have promoted forest development across the continent allowing migration to northern forests, a scenario proposed by Lucas et al. (2011).

A montane migration may have been via the Andes Mountains, which reached current elevations only after the late Miocene (Graham, 2011; Hughes et al., 2013). Before this period, the region was covered by montane forests (Graham, 2010). Before reaching their present elevations and influencing the current dry environments on their eastern side (Ortiz-Jaureguizar and Cladera, 2006; Graham, 2010), the Andes may have been covered by montane forests linking MAF to the northern part of South America. Andean uplift and formation of the Amazon basin probably influenced the initial diversification of lineages in northern South America. However, it is necessary to improve the resolution of the relationships at the deepest nodes of Myrcia s.l. for a better understanding of its initial diversification.

\subsection{Montane Atlantic Forest (MAF): origins and main centre of diversification}

The Montane Atlantic Forest region is the most important area in the biogeographic history of Myrcia s.l., as it is the most likely area of origin and main centre of diversification. The clade encompassing all Myrcia s.l. subgroups except clades 5 and 9 (node 261) has MAF as its ancestral area. Inside this group, the origin of most Myrcia s.l. subgroups is also linked to MAF, frequently with high probability (e.g., clades 2, 3, 6 and 7; Figs. 3 and 4; Table 2).

Calyptranthes is positioned in the clade delimited by node 261 but the oldest Calyptranthes lineages are associated with the Caribbean and Amazon Forest (see subsection 4.4). The terminal position of MAF lineages of Calyptranthes indicate that the group returned to diversify in the south; a clade close to the MAF lineage (node 219; Fig. 4; Table 2) has as ancestral area Amazon Forest and Caribbean suggesting an intermediate step to this expansion. Ultimately, node 225 delimits the MAF group of Calyptranthes (Fig. 4; Table 2). However, further sampling is required to confirm that no Calyptranthes from deeper nodes occur in the MAF.

The principle period of origin of the subgroup lineages was the Miocene. Pollen records (Lima, 1991; Biagolini et al., 2013) suggest forest vegetation in the MAF at that time. The Serra do Mar (main area of MAF) was already montane in the Miocene (Almeida and Carneiro, 1998), and it is likely that a wide area of montane forest already occurred along it (Morley, 2000; Burnham and Johnson, 2004). Miocene climate changes to colder climates may have had a central role in the simultaneous origin of MAF taxa. Perret et al. (2013) found that diversification of Atlantic Forest Gesneriaceae initiated around $30 \mathrm{Ma}$ and was influenced by the uplift of the Serra do Mar during the Oligocene, but before diversification of most subgroups of Myrcia s.l. The influence of tectonic events in the origin and evolution of Serra do Mar is still controversial (Hiruma et al., 2010). More data on ages, dates and elevation is necessary for accurate understanding of the role of geology in the diversification of Myrcia s.l. in MAF.

Recent studies have associated climate fluctuations with forest refugia and lineage diversification in MAF (Carnaval and Moritz, 2008; Martins, 2011). However results presented here suggest that most cladogenesis took place before the Quaternary. Nodes with Quaternary age usually do not have high statistical support; phylogeographic studies with selected taxa are encouraged to properly address this question.

The results presented here indicate that lineages of Myrcia s.l. from MAF have closer relationships with lineages from LAF; there is not a clear relationship between LAF and Amazon Forest, as indicated for other groups (Mori et al., 1981; Thomas et al., 1998). The coalescence of Amazon and Atlantic forests during the climatic fluctuations of the Neogene and Quaternary (Santos et al., 2007) apparently did not influence the diversification of Myrcia s.l.

\subsection{The Caribbean lineage}

The Caribbean has an important role in the diversification of Calyptranthes (=clade 1 ). While the crown node and the first lineage of Calyptranthes in this analysis appear to have originated in the Amazon Forest (see subsection 4.5), the Caribbean is the unique ancestral area of the subsequent two lineages (nodes 215 and 230; Fig. 4; Table 2). The stem nodes leading to these lineages (nodes 228 and 231) have ambiguous ancestral areas (Caribbean and Amazon Forest; Fig. 4; Table 2) preventing confirmation that

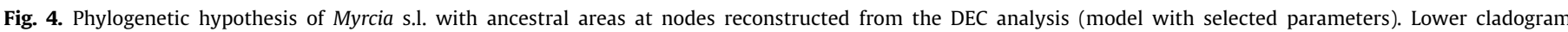

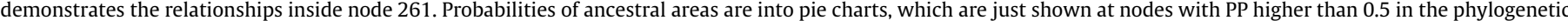

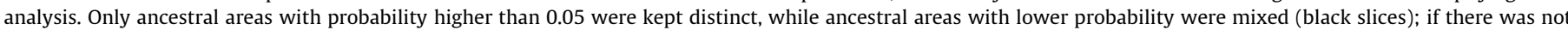

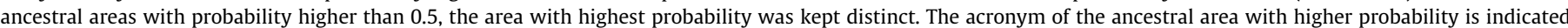

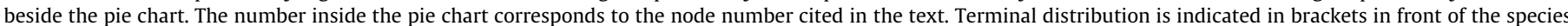

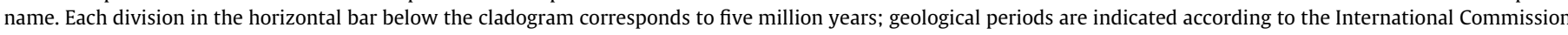

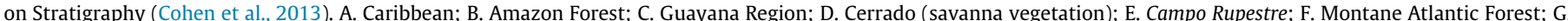

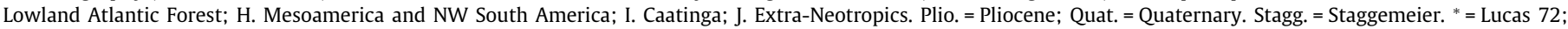
${ }^{* *}=$ Prevost 4716 . 

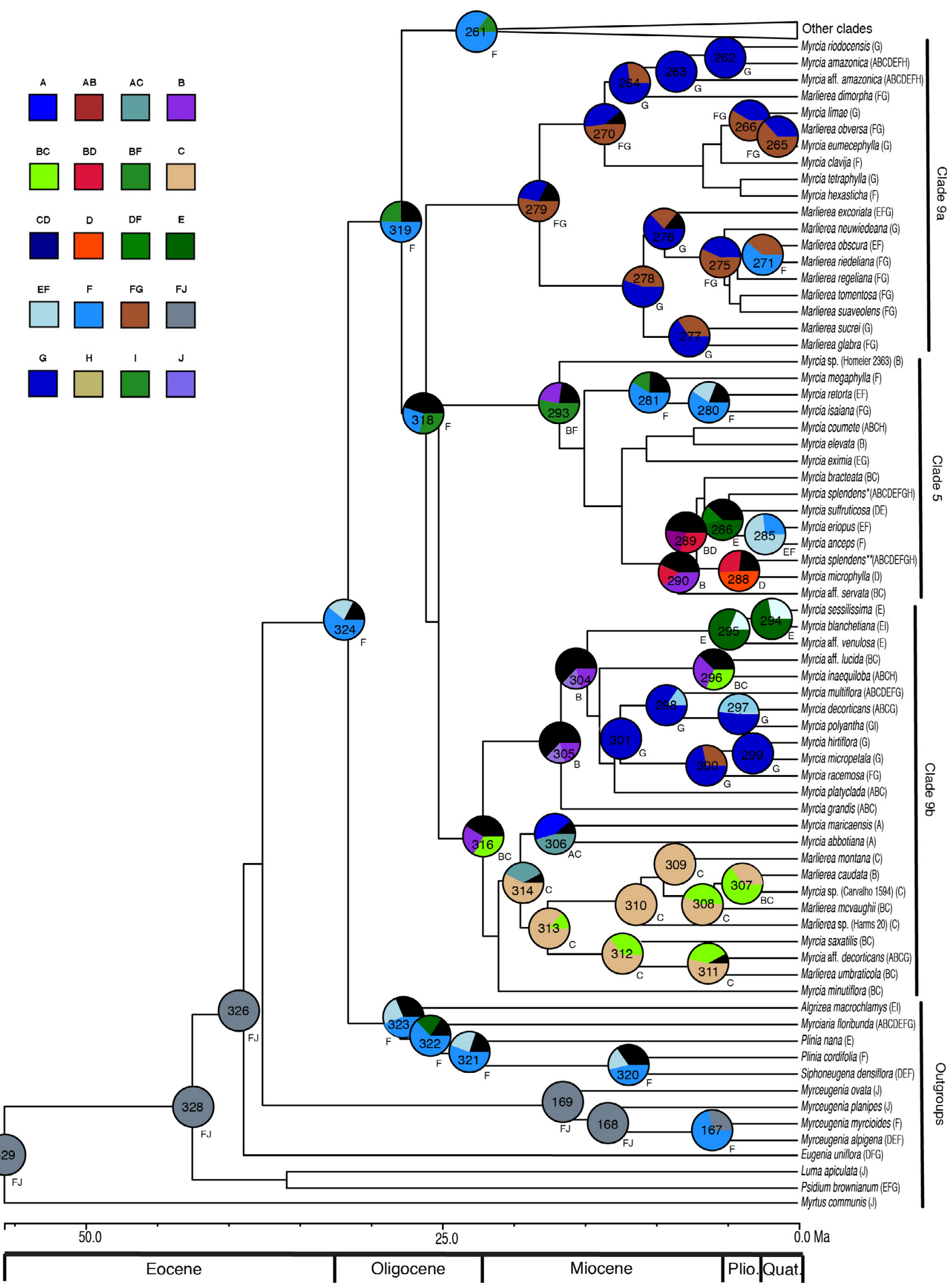


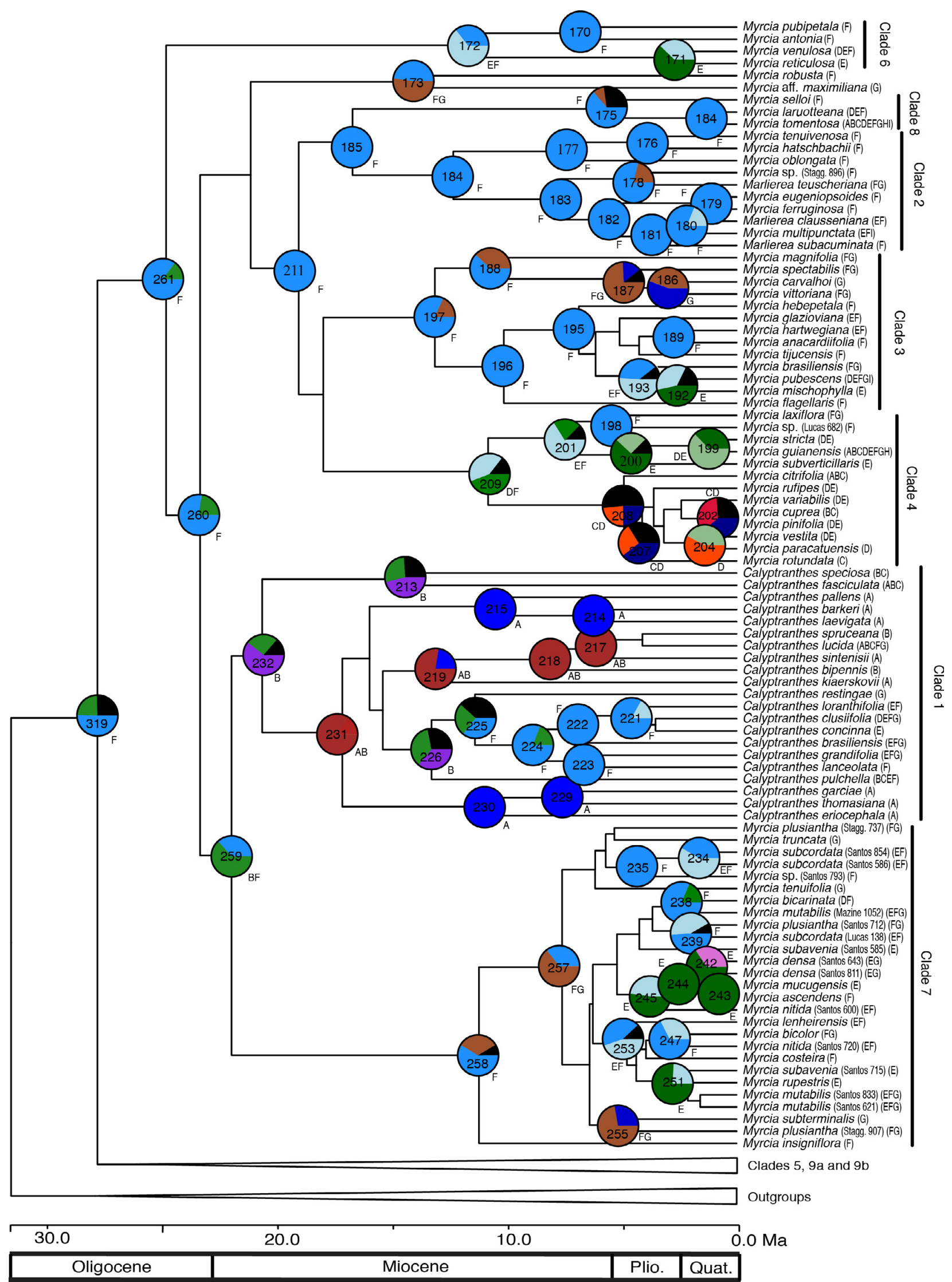

Fig. 4 (continued) 
these lineages were the result of a single or two independent events. Nevertheless, the high diversity of Calyptranthes in the Caribbean (ca. 130 spp.; Govaerts et al., 2016) and the association of old lineages of the genus with the Caribbean highlight the importance of the region in its diversification.

The placement of Calyptranthes in an inclusive Atlantic Forest clade but with its own origin in the Amazon suggests initial migration of a Calyptranthes ancestor to the north of South America and then to the Caribbean. The routes of this Calyptranthes ancestor may be similar to those proposed for Myrcia s.l. in subsection 4.2. Migration from the continent to the Caribbean islands may have been via various routes. At the time of the initial diversification of Calyptranthes (95\% HPD, 28.9-16.4 Ma), the Lesser Antilles had already emerged (Iturralde-Vinent and MacPhee, 1999; Graham, 2010), offering connection between South America and the Greater Antilles, where Calyptranthes has its main Caribbean diversity (McVaugh, 1969; Govaerts et al., 2016). Another possibility is through the Isthmus of Panama, whose appearance has been suggested to date from the end of the Oligocene (Montes et al., 2012). The latter scenario agrees with the proposal of Lucas et al. (2011) but at an earlier time. Bacon et al. (2013) proposed that some Arecaceae taxa used this route during a similar period. The South American origin of Caribbean Calyptranthes is congruent with other Caribbean taxa, such as Bactris (Arecaceae), Goetzeoidea (Solanaceae) and Protieae (Burseraceae) (Santiago-Valentín and Olmstead, 2004; Fine et al., 2014). Migration from the Caribbean to South America may have used the same routes (see subsection 4.3), still present during the diversification of Calyptranthes in the Atlantic Forest (95\% HPD, 18.3-8.8 Ma).

\subsection{Early nodes in the Guayana region}

The Guayana Region plus the Amazon is recovered as the ancestral area of clade $9 \mathrm{~b}(0.32$; Fig. 4 ; Table 2$)$, one of the first diverging lineages of Myrcia s.l. This arrangement agrees with the pattern found in Rapateaceae (Givnish et al., 2004), Bromeliaceae (Givnish et al., 2004, 2011), Gentianaceae (Helieae; Struwe et al., 2009), Eriocaulaceae (Trovó et al., 2013) and Astrocaryum (Roncal et al., 2013). However, the region is not the area of origin of Myrcia s.l. Low statistical support at the deepest nodes of Myrcia s.l. prevents the confirmation of the exact relationship with other areas. One of the main lineages of clade $9 \mathrm{~b}$ is almost restricted to the Guayana Region (node 314; Fig. 4), showing that endemism in the region is also found at the lineage level.

Node 295 of clade 9b (Fig. 4; Table 2) originated in the Campo Rupestre, suggesting links between these two montane areas (Giulietti and Pirani, 1988). However, reconstruction of ancestral areas inside clade $9 \mathrm{~b}$ is inconclusive, preventing firm conclusions about relationships between these areas. It is not clear if dispersal to the Campo Rupestre occurred through short steps or by longdistance dispersal. Clade 7 is mainly distributed in Montane Atlantic Forest and Campo Rupestre with three species in the Guayana Region (not included in the analysis), reinforcing the connection between these areas.

The 'Roraima group' is a geological formation bearing the typical habitat of vegetation of the region (Berry et al., 1995; Huber, 1995; Berry and Riina, 2005) and being the main source of sediment to the Rio Negro basin (Hoorn et al., 2010c). The surface of the Roraima group was at least partially exposed during the Paleogene and Neogene (Huber, 1995; Hoorn et al., 2010b) suggesting that geomorphological conditions similar to today existed there during the diversification of clade $9 \mathrm{~b}$. It is less likely that climate changes during the Miocene (Zachos et al., 2001; Graham, 2011) had an impact on the region due to its equatorial position. Thus, it is not clear if geological or climatic changes have influenced diversification of Myrcia s.l. in this region. Such relative stability of the region is invoked as the reason for the old lineages that are found there and that later colonized other areas (Roncal et al., 2013).

\subsection{The intriguing role Lowland Rainforests in the Myrcia s.l biogeography}

Lowland Forests areas have a counterintuitive role in the diversification of Myrcia s.l. lineages, since the high and low species diversity in LAF and Amazon, respectively, is not coincident with the origin of species rich lineage in each area. The Amazon Forest is not a main centre of endemism of Myrtaceae (McVaugh, 1968, 1969) however, initial diversification of some clades occurred there; e.g., it was recovered as the most probable ancestral area for Calyptranthes. The Amazon Forest appears relevant to the initial diversification of clade 5 , together with MAF, and clade 9b, together with the Guayana region. Other Amazonian species were included in the analysis, but these are scattered in different lineages suggesting origins from sporadic events. The diversification age of these clades corresponds to the period of the Pebas System (Ortiz-Jaureguizar and Cladera, 2006; Hoorn et al., 2010a, 2010b; Antonelli and Sanmartín, 2011), indicating no impediment to the diversification of these clades. Roncal et al. (2013) suggest that the diversification of Astrocaryum (Arecaceae) only took place after the drainage of Pebas system, the same pattern found in Rubiaceae (Antonelli et al., 2009).

Lowland Atlantic Forest boasts high Myrcia s.l. species diversity and endemism (Mori et al., 1983; Murray-Smith et al., 2008) but surprisingly it is only the ancestral area of clade 9a, shared with MAF (Fig. 4; Table 2). Besides the crown node of clade 9a and internal lineages, only small clades (node 186 , clade 3 ; node 300 , clade 9b) have LAF as its ancestral area. Together with low diversity in Amazon Forest, the few lineages with origin in LAF highlight the fact that montane environments are the main areas of diversification of Myrcia s.l.

High levels of diversity of Myrcia s.l. in lowland areas of Atlantic Forest (Tabuleiro Forest) may be related to their proximity to montane areas, allowing punctual speciation rather than development of species rich lineages. High species diversity in this area is embedded in clades that have their origin in other areas; this is proposed by Pennington and Dick (2010) regarding speciation of Andean montane taxa in surrounding lowland Amazon Forest. These patterns are further analogous to patterns suggested by Simon and Pennington (2012) for forest groups with punctual speciation in the adjacent Cerrado.

Tabuleiro Forests occur on sediments of the Barreiras formation, deposited during the Miocene (Thomas et al., 1998; Arai, 2006; Thomas and Barbosa, 2008). Evolution of clade 9a peaked during the Miocene (95\% HPD, 24.2-12.6 Ma), corresponding to the appearance of the new geology. The occurrence of lowland rain forests in the region is almost exclusive to this geological formation and it is likely that these forests only developed in the region after the deposition of the Barreiras formation. It is the first time that such relationship is observed. Biogeographic studies in other taxa are necessary to further investigate links between the deposition of the Barreiras formation and regional plant species diversification. Further paleo-vegetation data in the region is also required to accurately infer past landscapes.

\subsection{Lineages from open areas: Cerrado and Campo Rupestre}

The biogeographic analysis presented here suggests that the Cerrado has not played a major role in the evolution of Myrcia s.l. Despite Myrcia s.l. being one of the most species-rich groups in Cerrado species surveys (Oliveira-Filho and Fontes, 2000; Lucas et al., 2011), the number of endemic species is not high (about 30 
species; Sobral et al., 2016). Clade 4 contains many typical Cerrado species but most occur in other areas and ancestral area reconstruction is inconclusive. Only node 204 (Figs. 3 and 4; Table 2) has Cerrado as ancestral area, but statistical support for this node is low.

Unlike other Neotropical groups such as Andira and Mimosa (Fabaceae) and Eriotheca (Malvaceae) (Simon and Pennington, 2012), transition to savanna vegetation seems to be relatively uncommon in Myrcia s.l. Species of Myrcia s.l. rarely possess morphological features typical of Cerrado taxa such as thick corky bark and enlarged underground xylopodia (Simon et al., 2009; Simon and Pennington, 2012) and the absence of these features may have impeded colonization of Myrcia s.l. in the Cerrado. Among Myrcia s. 1. subgroups, only species of clades 4 and 5 regularly show xylopodia (e.g., Myrcia pinifolia - clade 4; Myrcia microphylla, Myrcia suffruticosa - clade 5). Clade 5 also may present the forestcerrado transition proposed by Simon et al. (2009) as it mostly comprises forest taxa but also some Cerrado endemic species. Future studies in these clades are important for better understanding of the role of Cerrado in Myrcia s.l. evolution. No significant relationship was found between Cerrado and Campo Rupestre taxa despite their geographical proximity.

As in the Cerrado, Myrcia s.l. species richness in Campo Rupestre is often high (e.g., Pirani et al., 2003) but endemism is low (about 10 species; based on Sobral et al., 2016). Results presented here suggest that Myrcia s.l. lineages did not expand significantly in the Campo Rupestre and the region is here suggested to have been the ancestral area of only two lineages in clades 7 and $9 b$ that have low diversity (nodes 244 and 295, respectively; Fig. 4; Table 2). The latter lineages have relatively recent origins (95\% HPD, 4.1-1.0 and 7.7-2.0 Ma, respectively) as reported for other taxa in the biome (Microlicieae [Melastomataceae] - Fritsch et al., 2004; Hoffmannseggella [Orchidaceae] - Antonelli et al., 2010). Climate change during Miocene cooling and appearance of fire four Ma ago are suggested to be drivers of diversification in this region (Antonelli et al., 2010; Fritsch et al., 2004).

Campo Rupestre environments share similarities to those of the Guiana Highland (Giulietti and Pirani, 1988), but while the former has low Myrcia s.l. endemism, endemism is high in the latter. Other Neotropical taxa have high species diversity in both regions (e.g., Eriocaulaceae - Trovó et al., 2013; Microlicia - Berry and Riina, 2005; Velloziaceae - Mello-Silva et al., 2011). A plausible cause for such difference is the continually wet climatic regime of the Guiana Highland, the conditions where Myrcia s.l. has higher diversity, while Campo Rupestre is more seasonal.

\section{Conclusions}

The analysis indicates that the origin of Myrcia s.l. took place in the Atlantic Forest, probably in forest vegetation according to paleo-vegetation records (Morley, 2000; Burnham and Johnson, 2004). Part of the group remained and diversified in the region, currently its main centre of diversity both in morphological variation and number of species. However, three old lineages (clades 5 , $9 \mathrm{a}$ and $9 \mathrm{~b}$ ) have their origin in northern areas, indicating that their ancestors moved relatively quickly to northern South America after the origin of Myrcia s.l. Some routes available during this period may have facilitated this migration (see section 4.3). Unfortunately, phylogenetic and geographical relationships between these lineages are not statistically supported. The Guayana Region and the Caribbean were also important for the evolution of major lineages (Myrcia s.l. subgroups). Despite low species diversity of Myrcia s.l. in the Amazon Forest, the region appears to be important in the initial diversification of old lineages, while LAF has high species diversity but is the area of origin of only one species rich lineage.
Geological events appear to have had an important role in the evolution of the Caribbean and Amazon forest lineages (IturraldeVinent and MacPhee, 1999; Hoorn et al., 2010a, 2010b), but other regions, especially the Atlantic Forest, were geologically stable. In these regions, climate changes during the Neogene were the most likely abiotic drivers of diversification. Diversification of Myrcia s.l. subgroups took place during the Miocene, between 22.1 Ma and 5.6 Ma, a pattern found for other Neotropical taxa (Rull, 2011; Hughes et al., 2013). The range of reported periods of lineage origin is large, possibly due to the availability of only a single calibration point. Unquestionable Neogene fossils of Myrcia s.l. are still lacking; their discovery will be essential to improve lineages divergence times.

The high number of species-rich lineages (including the crown node of subgroups) in montane areas (usually above $800 \mathrm{~m}$ ) suggests that Myrcia s.l. may be particularly adapted to such environments. If lineages arising directly from the oldest Myrteae nodes evolved in more temperate habitats, today's montane regions are more environmentally similar to ancestral areas and less change is required to occupy them than more tropical environments. Global climatic cooling during the Neogene may have facilitated this temperate to tropical transition. Fewer apparent transitions to lower altitudes and the low number of species rich lineages in such areas suggest the effect of Phylogenetic Niche Conservatism (Crisp and Cook, 2012). A better biogeographical understanding of tribe Myrteae will demonstrate how many times this transition occurred and allow inference of the occupation of temperate or tropical areas by stem lineages of Myrcia s.l. At this point, it is important to highlight the need for biological and field-based studies of physiological features, phenological traits, ecological interactions, among others. These data are essential to ground the analysis and for interpretation of model-based biogeography. Only holistic knowledge of the physiology, biology and ecology of Myrcia s.l. taxa will allow detailed, accurate investigation of the biogeographic process involved in its diversification.

\section{Acknowledgements}

M.F.S. acknowledges FAPESP for a PhD fellowship (grant\# 2010/09473-0 and grant\# 2012/14914-1), V.G.S. acknowledges FAPESP for a PD fellowship (grant\# 2016/02312-8), and P.T.S. acknowledges the financial support of $\mathrm{CNPq}$ (process number 308300/2012-2). We are grateful to Dion Devey, Edith Kapinos, Jim Clarkson, Laszlo Csiba, Laura Martinez-Suz and Thomas Booth for help in the laboratory at RBG Kew; to the colleagues of the Laboratório de Sistemática Vegetal for discussion about Biogeography; to Alexei Oskolski for information about Myrteae fossils.

\section{Appendix A. Supplementary material}

Supplementary data associated with this article can be found, in the online version, at http://dx.doi.org/10.1016/j.ympev.2017.01. 012 .

\section{References}

Almeida, F.F.M., Carneiro, C.D., 1998. Origem e evolução da Serra do Mar. Rev. Bras. Geociên. 28 (2), 135-150.

Almeida-Abreu, P.A., Renger, F.E., 2002. Serra do Espinhaço meridional: um orógeno de colisão do mesoproterozóico. Rev. Bras. Geociên. 32 (1), 1-14.

Antonelli, A., Nylander, J.A.A., Persson, C., Sanmartín, I., 2009. Tracing the impact of the Andean uplift on Neotropical plant evolution. Proc. Natl. Acad. Sci. U.S.A. 106 (24), 9749-9754

Antonelli, A., Verola, C.F., Parisod, C., Gustafsson, A.L.S., 2010. Climate cooling promoted the expansion and radiation of a threatened group of South American orchids (Epidendroideae: Laeliinae). Biol. J. Linn. Soc. 100, 597-607.

Antonelli, A., Sanmartín, I., 2011. Why are there so many plant species in the Neotropics? Taxon 60 (2), 403-414. 
Arai, M., 2006. A Grande Elevação Eustática do Mioceno e Sua Influência na Origem do Grupo Barreiras. Rev. Inst. Geociên. - USP 6 (2), 1-6.

Bacon, C., Mora, A., Warren, W., Jaramillo, C., 2013. Testing geological models of evolution of the Isthmus of Panama in a phylogenetic framework. Bot. J. Linn. Soc. 171, 287-300.

Berry, P.E., Hubber, O., Holst, B.K., 1995. Floristic analysis and phytogeography. In: Berry, P.E., Holst, B.K., Yatskievych, K. (Eds.), Flora of the Venezuelan Guayana, Introduction, vol. 1. Missouri Botanical Garden Press, St. Louis, pp. 161-191.

Berry, P.E., Riina, R., 2005. Insights into the diversity of the Pantepui flora and the biogeographic complexity of the Guayana Shield. Biol. Skr. 55, 145-167.

Biagolini, C.H., Bernardes-de-Oliveira, M.E.C., Caramês, A.G., 2013. Itaquaquecetuba Formation, São Paulo basin, Brazil: new angiosperm components of Paleogene Taphoflora. Braz. J. Geol. 43 (4), 639-652.

Biffin, E., Lucas, E.J., Craven, L.A., Costa, I.R., Harrington, M.G., Crisp, M.D., 2010 Evolution of exceptional species richness among lineages of fleshy-fruited Myrtaceae. Ann. Bot. 106 (1), 79-93.

Buerki, S., Forest, F., Alvarez, N., Nylander, J.A.A., Arrigo, N., Sanmartín, I., 2011. An evaluation of new parsimony-based versus parametric inference methods in biogeography: a case study using the globally distributed plant family Sapindaceae. J. Biogeogr. 38, 531-550.

Burnham, R.J., Graham, A., 1999. The history of Neotropical vegetation: new developments and status. Ann. Mo. Bot. Gard. 86, 546-589.

Burnham, R.J., Johnson, K.R., 2004. South American paleobotany and the origins of neotropical rainforests. Philos. Trans. Roy. Soc. B 359, 1595-1610.

Cabrera, A.L., Willink, A., 1980. Biogeografía de América Latina. 2nd ed. Serie de Biología, Monografía 13. General Secretaria of the Organization of American States, Washington, DC. 123 pp.

Calvente, A., Zappi, D.C., Forest, F., Lohmann, L.G., 2011. Molecular phylogeny, evolution and biogeography of South America Epiphytic Cacti. Int. J. Plant Sci. 172 (7), 902-914.

Carnaval, A.C., Moritz, C., 2008. Historical climate modeling predicts patterns of current biodiversity in the Brazilian Atlantic forest. J. Biogeogr. 35 (7), 11871201.

Cohen, K.M., Finney, S.C., Gibbard, P.L., Fan, J.-X., 2013. The ICS international chronostratigraphic chart. Episodes 36, 199-204.

CRIA, 2016. SpeciesLink Available from: <http://www.splink.cria.org.br/> (accessed on 7 Jul 2016).

Crisp, M.D., Cook, L.G., 2012. Phylogenetic niche conservatism: what are the underlying evolutionary and ecological causes? New Phytol. 196, 681-694.

Drummond, A.J., Ashton, B., Buxton, S., Cheung, M., Cooper, A., Duran, C., Heled, J., Kearse, M., Markowitz, S., Moir, R., Stones-Havas, S., Sturrock, S., Swidan, F., Thierer, T., Wilson, A., 2013. Geneious v. 6.1.6, available from http:// www.geneious.com.

Drummond, A.J., Rambaut, A., 2007. BEAST: Bayesian evolutionary analysis by sampling trees. Evol. Biol. 7, 214.

Edgar, R.C., 2004. MUSCLE: a multiple sequence alignment method with reduced time and space complexity. BMC Bioinformatics 5, 113.

Fiaschi, P., Pirani, J.R., 2009. Review of plant biogeographic studies in Brazil. J. Syst. Evol. 47, 477-496.

Fine, P.V.A., Zapata, F., Daly, D.C., 2014. Investigating processes of Neotropical rain forest tree diversification by examining the evolution and historical biogeography of the Protieae (Burseraceae). Evolution 68 (7), 1988-2004.

Fritsch, P.W., Almeda, F., Renner, S.S., Martins, A.B., Cruz, B.C., 2004. Phylogeny and circumscription of the near-endemic Brazilian tribe Microlicieae (Melastomataceae). Am. J. Bot. 91 (7), 1105-1114.

Gentry, A.H., 1982. Neotropical floristic diversity: phytogeographical connections between Central and South America, Pleistocene climatic fluctuations, or an accident of the Andean orogeny? Ann. Mo. Bot. Gard. 69, 557-593.

Giulietti, A.M., Pirani, J.R., 1988. Patterns of geographic distribution of some plant species from the Espinhaço Range, Minas Gerais and Bahia. In: Vanzolini, P.F. Heyer, W.R. (Eds.), Proceedings of a Workshop on Neotropical Distribution Patterns Held 12-16 January 1987. Academia Brasileira de Ciências, Rio de Janeiro.

Givnish, T.J., Barfuss, M.H.J., Ee, B..Van., Riina, R., Schulte, K., Horres, R., Gonsiska, P. A. Jabaily, R.S., Crayn, D.M., Smith, J.A.C., Winter, K., Brown, G.K., Evans, T.M. Holst, B.K., Luther, H., Till, W., Zizka, G., Berry, P.E., Sytsma, K.J., 2011. Phylogeny, adaptative radiation, and historical biogeography in Bromeliaceae: insights from an eight-locus plastid phylogeny. Am. J. Bot. 98 (5), 872-895.

Givnish, T.J., Millam, K.C., Evans, T.M., Hall, J.C., Pires, J.C., Berry, P.E., Sytsma, K.J. 2004. Ancient vicariance or recent long-distance dispersal? Inferences about phylogeny and South American-African disjunctions in Rapateaceae and Bromeliaceae based on $n d h f$ sequence data. Int. J. Plant Sci. 165 (4 Suppl.) S35-S54.

Govaerts, R., Sobral, M., Ashton, P., Barrie, F., Holst, B., Landrum, L., Lucas, E. Matsumoto, K., Mazine, F., Proença, C., Soares-Silva, L., Wilson, P., Nic Lughadha, E., 2016. Myrtaceae. In: World Checklist of Myrtaceae. Facilitated by the Royal Botanic Gardens, Kew. Published on the Internet http://apps.kew.org/wcsp/ 2016.

Graham, A., 2010. Late Cretaceous and Cenozoic History of Latin American Vegetation and Terrestrial Environments. Missouri Botanical Garden Press, St. Louis.

Graham, A., 2011. The age and diversification of terrestrial New World ecosystems through Cretaceous and Cenozoic time. Am. J. Bot. 98, 336-351.

Graham, A., 2012. Sequencing new world ecosystems: comparison of the Cretaceous and Cenozoic appearance of habitats with biome-characterizing plant groups. Ann. Mo. Bot. Gard. 98 (4), 524-538.
Harley, R.M., 1995. Introduction. In: Stannard, B.L. (Ed.), Flora of the Pico das Almas, Chapada Diamantina, Bahia, Brazil. Royal Botanical Gardens, Kew, pp. 1-42.

Hiruma, S.T., Riccomini, C., Modenesi-Gauttieri, M.C., Hackspacher, P.C., Hadler Neto, J.C., Franco-Magalhães, A.O.B., 2010. Denudation history of the Bocaina Plateau, Serra do Mar, southeastern Brazil: relationships to Gondwana breakup and passive margin development. Gondwana Res. 18, 674-687.

Hoorn, C., Wesselingh, F.P., Hovikoski, J., Guerrero, J., 2010a. The development of the Amazonian mega-wetland (Miocene; Brazil, Colombia, Peru, Bolivia). In: Hoorn, C., Wesselingh, F.P. (Eds.), Amazonia: Landscape and Species Evolution - A Look into the Past. Blackwell Publishing Ltd., West Sussex, pp. 123-142.

Hoorn, C., Wesselingh, F.P., ter Steege, H., Bermudez, M.A., Mora, A., Sevink, J., Sanmartín, I., Sanchez-Meseguer, A., Anderson, C.L., Figueiredo, J.P., Jaramillo, C., Riff, D., Negri, F.R., Hooghiemstra, H., Lundberg, J., Stadler, T., Sarkinen, T., Antonelli, A., 2010b. Amazonia through time: Andean uplift, climate change, landscape evolution, and biodiversity. Science 330, 927-931.

Hoorn, C., Roddaz, M., Dino, R., Soares, E., Uba, C., Ochoa-Lozano, D., Mapes, R. 2010c. The Amazonian Craton and its influence on past fluvial systems (Mesozoic-Cenozoic, Amazonia). In: Hoorn, C., Wesselingh, F.P. (Eds.), Amazonia: Landscape and Species Evolution - A Look into the Past. Blackwell Publishing Ltd., West Sussex, pp. 103-122.

Huber, O., 1995. Geography and physical features. In: Berry, P.E., Holst, B.K., Yatskievych, K. (Eds.), Flora of the Venezuelan Guayana, vol. 1. Missouri Botanical Garden Press, St. Louis, pp. 1-61.

Hughes, C.E., Pennington, R.T., Antonelli, A., 2013. Neotropical plant evolution: assembling the big picture. Bot. J. Linn. Soc. 171, 1-18.

InsideWood. 2004-onwards. Available in: <http://insidewood.lib.ncsu.edu/search>. Accessed on 20 Nov 2016.

Iturralde-Vinent, M.A., MacPhee, R.D.E., 1999. Paleogeography of the Caribbean region: implications for Cenozoic Biogeography. Bull. Am. Mus. Nat. Hist. 238, $1-95$.

Jaramillo, C., Hoorn, C., Silva, S.A.F., Leite, F., Herrera, F., Quiroz, L., Dino, R., Antonioli, L., 2010. In: Hoorn, C., Wesselingh, F.P. (Eds.), Amazonia: Landscape and Species Evolution - A Look into the Past. Blackwell Publishing Ltd., West Sussex, pp. 317-334.

Köppen, W., 1948. Climatologia con un estudio de los climas de la tierra. Fondo de Cultura Economica, Buenos Aires.

Labiak, P.H., Sundue, M., Rouhan, G., Hanks, J.G., Mickel, J.T., Moran, R.C., 2014. Phylogeny and historical biogeography of the Lastreopsid ferns (Dryopteridaceae). Am. J. Bot. 101 (7), 1207-1228.

Ladiges, P.Y., Udovicic, F., Nelson, G., 2003. Australian biogeographical connections and the phylogeny of large genera in the plant family Myrtaceae. J. Biogeogr. 30, 989-998.

Lima, M.R., 1991. Uma década de estudos palinológicos em sedimentos terciários continentais da região Sudeste do Brasil. Bol. Inst. Geociên. USP Publ. Esp. 9, 125-129.

Lohmann, L.G., Bell, C.D., Calió, M.F., Winkworth, R.C., 2013. Pattern and timing of biogeographical history in the Neotropical tribe Bignonieae (Bignoniaceae). Bot. J. Linn. Soc. 171, 154-170.

Lucas, E.J., Harris, S.A., Mazine, F.F., Belsham, S.R., Nic Lughadha, E.M., Telford, A., Gasson, P.E., Chase, M.W., 2007. Suprageneric phylogenetics of Myrteae, the generically richest tribe in Myrtaceae (Myrtales). Taxon 56, 1105-1128.

Lucas, E.J., Matsumoto, K., Harris, S.A., Nic Lughadha, E.M., Benardini, B., Chase, M. W., 2011. Phylogenetics, morphology, and evolution of the large genus Myrcia s. I. (Myrtaceae). Int. J. Plant Sci. 172 (7), 915-934.

Lucas, E.J., Wilson, C.E., Lima, D.F., Sobral, M., Matsumoto, K., 2016. A conspectus of Myrcia sect. Aulomyrcia (Myrtaceae). Ann. Mo. Bot. Gard. 101, 648-698.

Martins, F.M., 2011. Historical biogeography of the Brazilian Atlantic forest and the Carnaval-Moritz model of Pleistocene refugia: what do phylogeographical studies tell us? Bot. J. Linn. Soc. 104, 499-509.

McVaugh, R., 1968. The genera of American Myrtaceae - an interim report. Taxon 17, 354-418.

McVaugh, R., 1969. Myrtaceae. In: Maguire, B. et al., Botany of the Guayana Highland - Part VIII. Memoirs of the New York Botanical Garden 18: 55-286.

Mello-Silva, R., Santos, D.Y.A.C., Salatino, M.L.F., Motta, L.B., Cattai, M.B., Sasaki, D., Lovo, J., Pita, P.B., Rocini, C., Rodrigues, C.D.N., Zarrei, M., Chase, M.W., 2011. Five vicarious genera from Gondwana: the Velloziaceae as shown by molecules and morphology. Ann. Bot. 108, 87-102.

Miller, M.A., Pfeiffer, W., Schwartz, T., 2010. Creating the CIPRES Science Gateway for inference of large phylogenetic trees. Proceedings of the Gateway Computing Environments Workshop (GCE), pp. 1-8. New Orleans, LA.

Montes, C., Cardona, A., McFadden, R., Morón, S.E., Silva, C.A., Restrepo-Moreno, S., Ramírez, D.A., Hoyos, N., Wilson, J., Farris, D., Bayona, G.A., Jaramillo, C.A. Valencia, V., Bryan, J., Flores, J.A., 2012. Evidence for middle Eocene and younger land emergence in central Panama: Implications for Isthmus closure. Geol. Soc. Am. Bull. 10, 1130. http://dx.doi.org/10.1130/B30528.1.

Mori, S.A., Boom, B.M., Prance, G.T., 1981. Distribution patterns and conservation of eastern Brazilian coastal forest tree species. Brittonia 33, 233-245.

Mori, S.A., Boom, B.M., Carvalho, A.M., Santos, T.S., 1983. Ecological importance of Myrtaceae in an eastern Brazilian wet forest. Biotropica 15 (1), 68-70.

Morley, R.J., 2000. Origin and Evolution of Tropical Rainforests. Wiley, Chichester.

Morrone, J.J., 2006. Biogeographic areas and transition zones of Latin America and the Caribbean Islands based on panbiogeographic and cladistics analyses of the entomofauna. Annu. Rev. Entomol. 51, 467-494.

Morrone, J.J., 2014. Cladistic biogeography of the Neotropical region: identifying the main events in the diversification of the terrestrial biota. Cladistics 30 (2), 202 214. 
Murillo-A, J., Stuessy, T.F., Ruiz, E., 2016. Explaining disjunct distributions in the flora of southern South America: evolutionary history and biogeography of Myrceugenia (Myrtaceae). J. Biogeogr. 43 (5), 979-990.

Murray-Smith, C., Brummitt, N.A., Oliveira-Filho, A.T., Bachman, S., Moat, J., Nic Lughadha, E.M., Lucas, E.J., 2008. Plant diversity hotspots in the Atlantic coastal forests of Brazil. Conserv. Biol. 23 (1), 151-163.

Nylander, J.A.A., 2004. MrModeltest2. Version 2. Evolutionary Biology Centre, Uppsala University. http://www.abc.se/ nylander.

Oliveira-Filho, A.T., Fontes, M.A.L., 2000. Patterns of floristic differentiation among Atlantic forests in SE Brazil and the influence of climate. Biotropica 32, 793-810.

Oliveira-Filho, A.T., Jarenkow, J.A., Rodal, M.J.N., 2006. Floristic relationships of seasonally dry forests of eastern South America based on tree species distribution patterns. In: Pennington, R.T., Ratter, J.A., Lewis, G.P. (Eds.), Neotropical Savannas and Dry Forests: Plant Diversity, Biogeography and Conservation. CRC Press, Boca Raton, FL, pp. 159-192.

Ortiz-Jaureguizar, E., Cladera, G.A., 2006. Paleoenvironmental evolution of southern South America during the Cenozoic. J. Arid Environ. 66, 498-532.

Pennington, R.T., Dick, C.W., 2004. The role of immigrants in the assembly of the South American rainforest tree flora. Philos. Trans. Roy. Soc. Lond. B 359, $1611-$ 1622.

Pennington, R.T., Dick, C.W., 2010. Diversification of the Amazonian flora and its relation to key geological and environmental events: a molecular perspective. In: Hoorn, C., Wesselingh, F.P. (Eds.), Amazonia: Landscape and Species Evolution - A Look into the Past. Blackwell Publishing Ltd., West Sussex, pp. 373-385.

Perret, M., Chautems, A., Araujo, A., Salamin, N., 2013. Temporal and spatial origin of Gesneriaceae in the New World inferred from plastid DNA sequences. Bot. J. Linn. Soc. 171, 61-79.

Perret, M., Chautems, A., Spichiger, R., 2006. Dispersal-vicariance analyses in the tribe Sinningieae (Gesneriaceae): a clue to understanding biogeographical history of the Brazilian Atlantic forest. Ann. Mo. Bot. Gard. 93 (2), 340-358.

Pigg, K.B., Stockey, R.A., Maxwell, S.L., 1993. Paleomyrtinaea, a new genus of permineralized myrtaceous fruits and seeds from the Eocene of British Columbia and Paleocene of North Dakota. Can. J. Bot. 71, 1-9.

Pirani, J.R., Mello-Silva, R., Giulietti, A.M., 2003. Flora de Grão-Mogol, Minas Gerais, Brasil. Bol. Bot. Univ. São Paulo 21 (1), 1-24.

Poole, I., Mennega, A.M.W., Cantrill, D.J., 2003. Valdivian ecosystems in the Late Cretaceous and Early Tertiary of Antarctica: further evidence from myrtaceous and eucryphiaceous fossil wood. Rev. Palaeobot. Palynol. 124, 9-27.

Ragonese, A.M., 1980. Lenos fosiles de dicotiledoneas del Paleoceno de Patagonia, Argentina: 1. Myrceugenia chubutense, n. sp. (Myrtaceae). Ameghiniana 17, 297-311.

Rambaut A. Suchard, M., Drummond, A.J., 2013. Tracer. Version 1.4.1. http://tree. bio.ed.ac.uk/software/tracer.

Rapini, A., Ribeiro, P.L., Lambert, S., Pirani, J.R., 2008. A flora dos campos rupestres da Cadeia do Espinhaço. Megadiversidade 4 (1-2), 16-24.

Ree, R.H., Smith, S.A., 2008. Maximum likelihood inference of geographic range evolution by dispersal, local extinction, and cladogenesis. Syst. Biol. 57 (1), 414.

Richardson, J.E., Pennington, R.T., Pennington, T.D., Hollingsworth, P.M., 2001. Rapid diversification of a species-rich genus of neotropical rain forest trees. Science 293, 2242-2245.

Roncal, J., Khan, F., Millan, B., Couvreur, T., Pintaud, J.C., 2013. Cenozoic colonization and diversification patterns of tropical American palms: evidence from Astrocaryum (Arecaceae). Bot. J. Linn. Soc. 171, 120-139.

Ronquist, F., 1997. Dispersal-vicariance analysis: a new approach to the quantification of historical biogeography. Syst. Biol. 46, 195-203.

Rull, V., 2011. Neotropical biodiversity: timing and potential drivers. Trends Ecol. Evol. 26, 508-513.

Saadi, A., 1995. A geomorfologia da Serra do Espinhaço em Minas Gerais e de suas margens. Geonomos 3 (1), 41-63.

Santiago-Valentín, E., Olmstead, R.G., 2004. Historical biogeography of Caribbean plants: introduction to current knowledge and possibilities from a phylogenetic perspective. Taxon 53 (2), 299-319.

Santos, A.M.M., Silva, J.M.C., Tabarelli, M., 2007. Biogeographical relationships among tropical forests in northeastern Brazil. J. Biogeogr. 34, 437-446.

Santos, M.F., Sano, P.T., Forest, F., Lucas, E., 2016. Phylogeny, morphology and circumscription of Myrcia sect. Sympodiomyrcia (Myrcia s.l., Myrtaceae). Taxon 65, 759-774.
Silveira, F.A.O., Negreiros, D., Barbosa, N.P.U., Buisson, E., Carmo, F.F., Carstensen, D. W., Conceição, A.A., Cornelissen, T.G., Echternacht, L., Fernandes, G.W., Garcia, Q. S., Guerra, T.J., Jacobi, C.M., Lemos-Filho, J.P., Stradic, S.L., Morellato, L.P.C., Neves, F.S., Oliveira, R.S., Schaefer, C.E., Viana, P.L., Lambers, H., 2016. Ecology and evolution of plant diversity in the endangered campo rupestre: a neglected conservation priority. Plant Soil. http://dx.doi.org/10.1007/s11104-015-2637-8.

Simon, M.F., Grether, R., Queiroz, L.P., Skema, C., Pennington, R.T., Hughes, C.E. 2009. Recent assembly of the Cerrado, a Neotropical plant diversity hotspot, by in situ evolution of adaptations to fire. Proc. Natl. Acad. Sci. U.S.A. 106 (48) 20359-20364.

Simon, M.F., Pennington, R.T., 2012. The evolution of adaptations of woody plants in the savannas of the Brazilian Cerrado. Int. J. Plant Sci. 173, 711-723.

Sobral, M., Proença, C., Souza, M., Mazine, F., Lucas, E., 2016. Myrtaceae. In: Lista de Espécies da Flora do Brasil. Jardim Botânico do Rio de Janeiro. Available in: <http://reflora.jbrj.gov.br/jabot/floradobrasil/FB10660>. Accessed on 7 Jul 2016.

Staggemeier, V.G., Diniz-Filho, J.A.F., Forest, F., Lucas, E., 2015. Phylogenetic analysis in Myrcia section Aulomyrcia and inferences on plant diversity in the Atlantic rainforest. Ann. Bot. 115 (5), 747-761.

Struwe, L., Kadereit, J.W., Klackenberg, J., Nilsson, S., Thiv, M., Hagen, K.B. von, Albert, V.A., 2009. Systematics, character evolution, and biogeography of Gentianaceae, including a new tribal and subtribal classification. In: Struwe L., Albert, V.A. (Eds.), Systematics and Natural History. Cambridge University Press, Cambridge.

Swofford, D.L., 2002. PAUP*; Phylogenetic Analysis Using Parsimony (*and Other Methods), Version 4. Sinauer, Sunderland, Massachusetts, USA.

Sytsma, K.J., Litt, A., Zjhra, M.L., Pires, J.C., Nepokroeff, M., Conti, E., Walker, J., Wilson, P.G., 2004. Clades, clocks, and continents: historical and biogeographical analysis of Myrtaceae, Vochysiaceae, and relatives in the Southern Hemisphere. Int. J. Plant Sci. 165, S85-S105.

Thomas, W.W., Barbosa, M.R.V., 2008. Natural vegetation types in the Atlantic coastal forest of northeastern Brazil. In: Thomas, W.W. (Ed.), The Atlantic Coastal Forest of Northeastern Brazil. The New York Botanical Garden Press, New York, pp. 6-20.

Thomas, W.W., Carvalho, A.M.V., Amorim, A.M.A., Garrison, J., Arbeláez, A.L., 1998 Plant endemism in two forests in southern Bahia, Brazil. Biodivers. Conserv. 7 , $311-322$.

Thornhill, A.H., Popple, L.W., Carter, R.J., Ho, S.Y., Crisp, M.D., 2012. Are pollen fossils useful for calibrating relaxed molecular clock dating of phylogenies? A comparative study using Myrtaceae. Mol. Phylogenet. Evol. 63, 15-27.

Trovó, M., Andrade, M.J.G., Sano, P.T., Ribeiro, P.L., van den Berg, C., 2013. Molecular phylogenetics and biogeography of Neotropical Paepalanthoideae with emphasis on Brazilian Paepalanthus (Eriocaulaceae). Bot. J. Linn. Soc. 171 225-243.

Van der Hammen, T., 1983. The Palaeoecology and Palaeogeography of Savannas. In: Bourlière, F. (Ed.), Tropical Savannas. Elsevier Science Pub. Co., New York, pp. 19-35.

Vasconcelos, T.N.C., Proença, C.E.B., Ahmad, B., Aguilar, D.S., Aguilar, R., Amorim, B. S., Campbell, K., Costa, I.R., De-Carvalho, P.S., Faria, J.E.Q., Giaretta, A., Kooij, P. W., Lima, D.F., Mazine, F.F., Peguero, B., Prenner, G., Santos, M.F., Soewarto, J., Wingler, A., Lucas, E.J., 2017. Myrteae phylogeny, calibration, biogeography and diversification patterns: Increased understanding in the most species rich tribe of Myrtaceae. Mol. Phylogenet. Evol. 109, 113-137.

Wesselingh, F.P., Hoorn, C., Kroonenberg, S.B., Antonelli, A., Lundberg, J.G., Vonhof, H.B., Hooghiemstra, H., 2010. On the origin of Amazonian landscapes and biodiversity: a synthesis. In: Hoorn, C., Wesselingh, F.P. (Eds.), Amazonia: Landscape and Species Evolution - A Look into the Past. Blackwell Publishing Ltd., West Sussex, pp. 421-432.

Wilson, C.E., Forest, F., Devey, D.S., Lucas, E.V., 2016. Phylogenetic relationships in Calyptranthes (Myrtaceae) with particular emphasis on its monophyly relative to Myrcia s. 1. Syst. Bot. 41, 378-386.

Wilson, P.G., O’Brien, M.M., Heslewood, M.M., Quinn, C.J., 2005. Relationships within Myrtaceae sensu lato based on a matK phylogeny. Plant Syst. Evol. 251, 3-19.

Yu, Y., Harris, A.J., Blair, C., He, X., 2015. RASP (Reconstruct Ancestral State in Phylogenies): a tool for historical biogeography. Mol. Phylogenet. Evol. 87, 4649.

Zachos, J., Pagani, M., Sloan, L., Thomas, E., Billups, K., 2001. Trends, rhythms, and aberrations in global climate 65 Ma to present. Science 292, 686-693. 